\title{
AMERICAN SOCIETY FOR
}

\section{CLIN ICAL \\ INVESTIGATION}

68TH ANNUAL MEETING - INCLUDING PROGRAMS FOR

THE AMERICAN FEDERATION FOR CLINICAL RESEARCH

AND THE ASSOCIATION OF AMERICAN PHYSICIANS

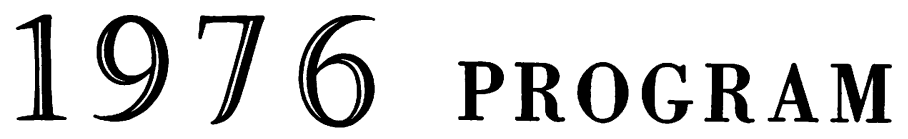

MAY 1-4 - HADDON HALL - ATLANTIC CITY

68th Annual Meeting of The American Society for Clinical

Investigation

33rd Annual Meeting of The American Federation for Clinical

Research

$\mathbf{v}$

89th Annual Meeting of The Association of American Physicians xli 
Program

Sixty-eighth Annual Meeting

THE AMERICAN SOCIETY FOR CLINICAL INVESTIGATION

Pennsylvania Room, Haddon Hall

Atlantic City, New Jersey

MONDAY, MAY 3, 1976

MORNING SESSION 9:00 A.M.

First Business Session 9:00 A.M.

Presidential Address

Laurence E. Earley

Scientific Session

Laurence E. Earley, Presiding

1. CHARACTERIZATION OF ANTI-INSULIN RECEPTOR ANTIBODIES: A CAUSE OF INSULINRESISTANT DIABETES IN MAN. J.S. Flier," C.R. Kahn* and J. Roth, Bethesda, Maryland. page 457A

2. SOMATOSTATIN AND GLUCAGON IN DIABETES: FAILURE OF GLUCAGON SUPPRESSION TO IMPROVE INTRAVENOUS GLUCOSE TOLERANCE AND EVIDENCE OF AN EFFECT OF SOMATOSTATIN ON GLUCOSE ABSORPTION. J. Wahren* and P. Felig, Stockholm, Sweden, and New Haven, Connecticut. page 461A

3. ALPHA-ADRENERGIC RECEPTORS: IDENTIFICATION BY $\left[{ }^{3} \mathrm{H}\right]$ DIHYDROERGOCRYPTINE BINDING. L.T. Williams* and R.J. Lefkowitz (Intr. by A.G. Wallace), Durham, North Carolina.

page $431 \mathrm{~A}$

4. A STEROID HORMONE RECEPTOR CAN "TURN ON" TRANSCRIPTION OF A SPECIFIC EUCARYOTIC GENE. R. Schwartz," C. Chang," W. Schrader,* and B.W. O'Malley, Houston, Texas.

page $430 \mathrm{~A}$

5. THE EFFECT OF A PEPTIDE INHIBITOR OF ADENYLATE CYCLASE ON CYCLIC ADENOSINE MONOPHOSPHATE-LINKED FUNCTIONS IN CANINE CARDIAC SARCOPLASMIC RETICULUM. M.L. Entman,* D.C. Lehotay," E.P. Bornet,* L.A. Bricker,* and G.S. Levey, Houston, Texas, and Miami, Florida. page $419 A$

*By invitation.

ii

1976 Programs $\cdot$ ASCI-AFCR-AAP
6. HETEROGENEITY OF GENE DEFECTS IN $\beta$ THALASSEMIA. F. Ramirez, * B. Luppis, ${ }^{*}$ R. Gambino,* S. Musumeci,* G. Schiliro,* G. Pizzarelli,* G. Russo, * P.A. Marks, ${ }^{* *}$ and A. Bank, New York, New York. page $442 A$

7. POSSIBLE ROLE OF T LYMPHOCTYES IN THE PATHOGENESIS OF APLASTIC ANEMIA. W.A. Kagan,* J.A. Ascensao,* R.N. Pahwa,* M.A.S. Moore,* and R.A. Good,** New York, New York. page $440 A$

8. POLYCYTHEMIA VERA: DEMONSTRATION OF NORMAL AND ABNORMAL STEM CELLS AND CHARACTERIZATION OF THE IN VITRO RESPONSE TO ERYTHROPOIETIN. J.F. Prchal,* J.W. Adamson, S. Murphy, * L. Steinmann, * and P.J. Fialkow, Seattle, Washington, and Philadelphia, Pennsylvania. page 442A

9. DEFECTIVE LEUKOTAXIS IN CANCER PATIENTS. P.A. Ward, T. Anton,* and E. Maderazo,* Farmington and Hartford, Connecticut. page $463 \mathrm{~A}$

10. MONOCYTES OF BREAST CANCER PATIENTS EXPRESS ANTITUMOR IMMUNITY AS MEASURED BY LEUKOCYTE ADHERENCE INHIBITION IN TEST TUBES. D.M.P. Thomson,* N. Grosser,* and J. Marti* (Intr. by S.O. Freedman), Montreal, Quebec, Canada. page 463A

11. SELF-INDUCED LOSS OF CALCITONIN RECEPTORS IN BONES: A POSSIBLE EXPLANATION FOR "ESCAPE." D.R. Wright,* J.L. Ivey," and A.H. Tashjian, Jr.,* (Intr. by P.R. Larsen), Boston, Massachusetts. page $461 A$

12. THE BIOCHEMICAL BASIS OF OXYGEN TOXICITY IN GRANULOCYTES AND ALVEOLAR MACROPHAGES. M. Rister* and R.L. Baehner, Indianapolis, Indiana. 


\section{Second Business Session}

\section{Scientific Session}

13. EFFECT OF HISTAMINE ON CYCLIC ADENOSINE MONOPHOSPHATE AND CYCLIC GUANOSINE MONOPHOSPHATE IN VIVO IN CANINE LUNGS. D. Barnett, ${ }^{*}$ A. Zbinden,* S. Chesrown, ${ }^{*}$ M. Nisam,* K. Melmon, H. Bourne, and W. Gold, San Francisco, California. page $464 \mathrm{~A}$

14. CONTRACTION OF CORONARY ARTERIAL SMOOTH MUSCLE BY A SUBSTANCE RELEASED FROM PLATELETS: EVIDENCE THAT IT IS THROMBOXANE $A_{2}$. E.F. Ellis,* O. Oelz,* L.J. Roberts, ${ }^{*}$ A.S. Nies, ${ }^{*}$ and J.A. Oates, Nashville, Tennessee. page $419 A$

15. ANTIBODIES REACTING WITH CYTOPLASM OF SUBTHALAMIC AND CAUDATE NUCLEI NEURONS IN CHOREA AND ACUTE RHEUMATIC FEVER. G. Husby,* J.B. Zabriskie, ${ }^{* *}$ Z.H. Abdin,* and R.C. Williams, Jr., ${ }^{* *}$ Albuquerque, New Mexico; New York, New York; and Cairo, Egypt. page 447A

16. FUNCTIONAL ANALYSIS OF TWO SUBPOPULATIONS OF HUMAN T CELLS AND THEIR DISTRIBUTION IN IMMUNODEFICIENT PATIENTS. L. Moretta, ${ }^{*}$ S.R. Webb,* C.E. Grossi,* P.M. Lydyard,* and M.D. Cooper, Birmingham, Alabama.

page $448 \mathrm{~A}$

17. ABSENCE OF AN IMMUNOLOGIC BLOCKING FACTOR IN THE SERUM OF WOMEN WHO
CHRONICALLY ABORT. R.E. Rocklin,* J. Kitzmiller,* C.B. Carpenter, and J.R. David, Boston, Massachusetts. page $449 A$

18. THE HUMAN GLOMERULAR COMPLEMENT RECEPTOR: ITS ROLE IN IMMUNE-COMPLEX RENAL DISEASE. M.C. Gelfand,* M.L. Shin,* R.B. Nagle,* M.M. Frank, and I. Green,** Washington, D.C.; Baltimore and Bethesda, Maryland. page $467 \mathrm{~A}$

19. PRODUCTION OF ANTIBODY AGAINST HUMAN LEUKOCYTIC PYROGEN. C.A. Dinarello, ${ }^{*}$ L. Renfer, ${ }^{*}$ and S.M. Wolff, Bethesda, Maryland. page $452 \mathrm{~A}$

20. DUFFY BLOOD GROUP NEGATIVITY AND RESISTANCE TO VIVAX MALARIA. S.J. Mason,* L.H. Miller, * T. Shiroishi,* and J.A. Dvorak (Intr. by W.E. Paul), Bethesda, Maryland. page $453 \mathrm{~A}$

21. ELUCIDATION OF THE BIOCHEMICAL BASIS OF ACTION OF CHOLECYSTOKININ. T.P. Conlon,* J. Christophe, ${ }^{*}$ H.T. Shelby, ${ }^{*}$ E.K. Fransden, ${ }^{*}$ and J.D. Gardner, Bethesda, Maryland. page $432 \mathrm{~A}$

22. AN ENZYME IN LIVER PLASMA MEMBRANE WHICH CONVERTS BILIRUBIN MONOGLUCURONIDE TO BILIRUBIN DIGLUCURONIDE. P.L.M. Jansen,* J.R. Chowdhury,* E. Fischberg,* and I.M. Arias, New York, New York. page $433 A$

23. MECHANISM OF THE ELEVATED RENAL CLEARANCE OF AMYLASE: CLEARANCE OF CREATININE IN ACUTE PANCREATITIS. S.G. Johnson,* C. Ellis, ${ }^{*}$ B. Spring, ${ }^{*}$ and M.D. Levitt, Minneapolis, Minnesota.

page $433 \mathrm{~A}$

\section{Officers of the American Society for Clinical Investigation}

PRESIDENT

Laurence E. Earley

San Antonio, Texas

SECRETARY-TREASURER

Hibbard E. Williams

San Francisco, California

James R. Clapp

Durham, North Carolina

Edgar Haber

Boston, Massachusetts

\author{
PRESIDENT-ELECT \\ John S. Fordtran \\ Dallas, Texas
}

VICE-PRESIDENT
Harold J. Fallon
Richmond, Virginia

EDITOR

Jean D. Wilson

Dallas, Texas
COUNCILORS

Theodore C. Eickhoff

Denver, Colorado

Charles W. Parker

St. Louis, Missouri
De Witt S. Goodman New York, New York Leon E. Rosenberg New Haven, Connecticut 


\title{
THE AMERICAN FEDERATION FOR CLINICAL RESEARCH
}

\author{
Presents a Symposium \\ "FUTURE OF MEDICAL SPECIALIZATION: \\ IMPACT OF HEALTH MANPOWER LEGISLATION"
}

Saturday, May 1, 1976, 3:00 P.M.

\section{Pennsylvania Room II, Haddon Hall}

Moderator: Donald W. Seldin, The University of Texas Southwestern Medical School, Dallas, Texas.

Participants:

1. THEODORE COOPER, Assistant Secretary for Health, Department of Health Education and Welfare, Washington, D.C.

2. EDMUND D. PELLEGRINO, Chairman, Board of Directors, Yale-New Haven Medical Center, Inc., New Haven, Connecticut.

3. JOHN C. BECK, Professor of Medicine, University of California School of Medicine; Director, Clinical Scholars Program, The Robert J. Wood Johnson Foundation, San Francisco, California.

The purpose of this symposium is to explore the goals of pending health manpower legislation and the impact of this legislation on the training of future medical specialists. The position of the Government in developing this legislation will be presented. The importance of specialization will be put in perspective and a position favoring more general training at the expense of specialization will be presented. Adequate time is planned for discussion of this current topic. 
Program

Thirty-third Annual Meeting

THE AMERICAN FEDERATION FOR CLINICAL RESEARCH

\author{
Pennsylvania Room, Haddon Hall \\ Atlantic City, New Jersey \\ SUNDAY, MAY 2, 1976
}

GENERAL SESSION

David Challoner, Presiding

Business Session 8:30 A.M.

Scientific Session 9:00 A.M.

1. INHERITED HUMAN COLLAGEN LYSYL HYDROXYLASE DEFICIENCY: ASCORBIC ACID RESPONSE. L.J. Elsas, R.L. Miller,* and S.R. Pinnell, Atlanta, Georgia, and Durham, North Carolina. page $294 A$

2. REGULATION OF THE AFFINITY AND CONCENTRATION OF INSULIN RECEPTORS IN MAN. R.S. Bar,* P. Gorden,** J. Roth,** C.R. Kahn, and P. De Meyts, ${ }^{*}$ Bethesda, Maryland.

page $269 \mathrm{~A}$

3. EXPRESSION OF A HORMONE REGULATABLE GENE FOLLOWING INJECTION INTO A HETEROLOGOUS CELL. L. Chan, * P.O. Kohler, and B.W. O'Malley, Houston, Texas. page $270 A$

4. PROTECTION OF THE ISCHEMIC DOG MYOCARDIUM WITH L-CARNITINE. J.D. Folts, A.S. Shug, ${ }^{*}$ J.R. Koke,* and N. Bittar, Madison, Wiscon$\sin$.

page $217 \mathrm{~A}$

5. A CONTROLLED CLINICAL TRIAL OF COMPLIANCE-IMPROVING STRATEGIES IN PRIMARY HYPERTENSION. D.L. Sackett, R.B. Haynes, * E.S. Gibson,* D.W. Taylor,* B.C. Hackett, * R.S. Roberts, ${ }^{*}$ and A.L. Johnson,* Hamilton, Ontario, Canada.

page $249 A$

Presidential Address David Challoner

Intermission

\section{Scientific Session \\ Samuel Thier, Presiding}

6. CENTRIOLE, MICROTUBULE AND MICROFILAMENT ORIENTATION DURING HUMAN POLYMORPHONUCLEAR LEUKOCYTE CHEMOTAXIS. H.L. Malech, * R.K. Root, and J.I. Gallin, Bethesda, Maryland, and New Haven, Connecticut. page $314 \mathrm{~A}$

7. AN INHIBITOR OF MACROPHAGE CHEMOTAXIS PRODUCED BY NEOPLASMS. R. Snyderman and M.C. Pike, ${ }^{*}$ Durham, North Carolina.

page $336 \mathrm{~A}$

8. DIAMOND-BLACKFAN SYNDROME: LYMPHOCYTE-MEDIATED SUPPRESSION OF ERYTHROPOIESISS. R. Hoffman,* E.D. Zanjani, J. Vila,* R. Zalusky, ${ }^{* *}$ J.D. Lutton,* and L.R. Wasserman,** New York, New York.

page $311 \mathrm{~A}$

9. $\mathrm{HB}_{\mathrm{S}} \mathrm{Ag}$-POSITIVE HEPATITIS: PREDOMINANCE OF T-LYMPHOCYTES IN HEPATIC INFILTRATE. D.J. Miller,* J.M. Dwyer, and G. Klatskin,** New Haven, Connecticut.

page $289 \mathrm{~A}$

10. ETIOLOGY OF NONGONOCCOCAL URETHRITIS: CHLAMYDIA TRACHOMATIS AND UREAPLASMA UREALYTICUM. W.R. Bowie,* E.R. Alexander,* S-P. Wang,* J-S L. Lin,* and K.K. Holmes, Seattle, Washington, and Boston, Massachusetts.

page $341 \mathrm{~A}$
*By invitation.
**Senior member, AFCR.

1976 Programs $\cdot$ ASCI-AFCR-AAP 
Sponsored by

THE AMERICAN FEDERATION FOR CLINICAL RESEARCH

Chalfonte-Haddon Hall and LaFayette Hotels

Atlantic City, New Jersey

SATURDAY EVENING, MAY 1, 1976

Cardiovascular I, $\dagger$ Carolina Room, Chalfonte

Cardiovascular II, Music Room, Chalfonte

Clinical Epidemiology and Health Care Research, $\dagger$ Solarium, Haddon Hall

Clinical Nutrition, ${ }^{\ddagger}$ Ballroom, Sheraton Seaside

Endocrinology I, ${ }^{\dagger}$ Rutland Room, Haddon Hall

Gastroenterology I, Pennsylvania Room II, Haddon Hall

Hematology I, $\dagger$ Windsor Room, Haddon Hall

Immunology and Connective Tissue I, Pennsylvania Room I, Haddon Hall

Immunology and Connective Tissue Poster Session, Exhibit Hall
Infectious Disease I, $\dagger$ Pennsylvania Room III, Haddon Hall

Metabolism I, Vernon Room, Haddon Hall

Oncology, Garden Room, Haddon Hall

Pulmonary I, $\dagger^{\dagger}$ Teakwood Room, LaFayette

Renal and Electrolyte I, Viking Room, Haddon Hall

Renal and Electrolyte II, West Room, Haddon Hall

$\dagger$ Followed by Symposium.

${ }^{\ddagger}$ Sponsored jointly with the American Society for Clinical Nutrition.
Carolina Room, Chalfonte

7:00 P.M.

Virendra S. Mathur, Presiding

1. "REVERSE CORONARY STEAL" INDUCED BY METHOXAMINE FOLLOWING CORONARY ARTERY OCCLUSION IN DOGS. M. Chiariello, ${ }^{*}$ M.A. Davis,* and P.R. Maroko, Boston, Massachusetts.

page $212 \mathrm{~A}$

2. EARLY DEVELOPMENT OF COLLATERAL VESSELS AND THEIR PHARMACOLOGIC RESPONSE AFTER CORONARY ARTERY LIGATION. H.O. Hirzel, * E.H. Sonnenblick,** and E.S. Kirk, Bronx, New York.

page $223 A$

*By invitation

**Senior member, AFCR

vi

1976 Programs · ASCI-AFCR-AAP
3. COMPARISON OF NITROGLYCERIN-, NITROPRUSSIDE-, AND PHENTOLAMINE-INDUCED CHANGES IN CORONARY COLLATERAL FUNCTION. N. Capurro, * K.M. Kent, and S.E. Epstein, Bethesda, Maryland.

page $212 A$

4. EFFECTS OF SUSTAINED INCREASES IN EXTRACELLULAR POTASSIUM ON CORONARY RESISTANCE IN INTACT DOG HEARTS. R. Shuchleib,* L. Borda,* J. Davis,* and P. Henry, St. Louis, Missouri. page $240 A$

5. LOSS OF FUNCTIONAL INTEGRITY OF THE MICROVASCULATURE IN ISCHEMIC MYOCARDIUM. J.P. Connors, * P.N. West,* R. Roberts, C.S. Weldon, * B.E. Sobel, and J.R. Williamson,* St. Louis, Missouri.

page $213 \mathrm{~A}$ 
6. HEMODYNAMIC AND ANGIOGRAPHIC SIGNIFICANCE OF CORONARY ARTERY STENOSIS. J. Azorin,* J. Lespérance,* J. Frija,* P. Bielmann,* and M.G. Bourassa, ${ }^{* *}$ Montreal, Canada. page $207 A$

7. THE RELATIONSHIP BETWEEN PROGRESSIVE DECREASES IN LOCAL CORONARY PRESSURE AND FLOW AND REGIONAL CONTRACTILE ABNORMALITIES. V.S. Banka, M.M. Bodenheimer, K.B. Ramanathan,* S. Raina,* R. Levites, and R.H. Helfant, Philadelphia, Pennsylvania. page 208A

8. CONTRASTING EFFECTS OF DOPAMINE AND ISOPROTERENOL ON LOCAL ISCHEMIA. K.B. Ramanathan,* S. Raina,* M.M. Bodenheimer, V.S. Banka, and R.H. Helfant, Philadelphia, Pennsylvania.

page $236 \mathrm{~A}$
Symposium

"New Concepts in Cardiology"

Moderator: Douglas P. Zipes

Participants:

1. LESSONS LEARNED FROM MYOCARDIAL INFARCTION RESEARCH UNITS. Charles Rackley, University of Alabama, Birmingham, Alabama.

2. MYOCARDIAL IMAGING. Barry Zaret, Yale University, New Haven, Connecticut.

3. ECHOCARDIOGRAPHY. Harvey Feigenbaum, Indiana University, Indianapolis, Indiana.

4. ELECTROCARDIOGRAPHY. Douglas P. Zipes, Indiana University, Indianapolis, Indiana.

\section{Cardiovascular II}

\section{Music Room, Chalfonte \\ 7:00 P.M. \\ Allyn Mark, Presiding}

1. REDUCED CYCLIC ADENOSINE MONOPHOSPHATE AND ELEVATED CYCLIC GUANOSINE MONOPHOSPHATE IN INFARCTED MYOCARDIUM FOLLOWING CORONARY LIGATION. J. Wikman-Coffelt, ${ }^{* *}$ T. Kamiyama, R.R. Miller, A.F. Salel, and D.T. Mason, ${ }^{* *}$ Davis, California.

page $246 \mathrm{~A}$

2. ISCHEMIA INDUCED DISSOCIATION BETWEEN THE LENGTH AND VELOCITY OF MYOCARDIAL FIBER SHORTENING IN CONSCIOUS DOGS. M. Pagani,* S.F. Vatner, H. Baig, ${ }^{*}$ and E. Braunwald,** Boston and Southboro, Massachusetts.

page $234 A$

3. ABNORMAL MITOCHONDRIAL OXIDATIVE PHOSPHORYLATION OF ISCHEMIC MYOCARDIUM REVERSED BY ETHYLENEDIAMINETETRAACETIC ACID. C.F. Peng," J.J. Kane, ${ }^{*}$ M.L. Murphy, ${ }^{* *}$ and K.D. Straub, Little Rock, Arkansas. page $235 A$

4. INTENSIFICATION AND ACCELERATION OF ISCHEMIC CARDIAC INJURY DUE TO GLY-
COLYTIC BLOCKADE. C.S. Apstein, M. Mueller,* L. Hagopian, * and W.B. Hood, Jr., ${ }^{* *}$ Boston, Massachusetts. page $206 \mathrm{~A}$

5. METABOLIC SUPPORT OF VENTRICULAR FUNCTION IN PATIENTS WITH MYOCARDIAL INFARCTION BY AN INFUSION OF GLUCOSEINSULIN-POTASSIUM. J.A. Mantle, R.O. Russell,** W.J. Rogers, H.G. McDaniel, and C.E. Rackley, ${ }^{* *}$ Birmingham, Alabama. page $228 \mathrm{~A}$

6. ENHANCED SENSITIVITY TO PRESSOR AGENTS BY INDOMETHACIN IN NORMAL MAN. G.P. Guthrie, Jr., * F.H. Messerli,* O. Kuchel,** and J. Genest, ** Montreal, Quebec, Canada. page $220 \mathrm{~A}$

7. VENTRICULAR HYPERTROPHY: RELATIVE RATES OF PROGRESSION AND REGRESSION. M.L. Marcus,* D.L. Eckberg,* J. Braxmeier, and F.M. Abboud,* Iowa City, Iowa. page $229 \mathrm{~A}$

8. HYPERTHERMIC INSULT TO ISCHEMIC MYOCARDIUM: IMPLICATIONS OF FEVER AS AN ENERGY DRAINING PROCESS IN MYOCARDIAL INFARCT. A.J. Liedtke and H.C. Hughes, Hershey, Pennsylvania.

page $227 A$ 
Solarium, Haddon Hall

7:00 P.M.

Duke Baker and Steve Schroeder, Presiding

1. IMPACT OF NEW TECHNOLOGY-THE EMI SCANNER. W. Knaus* and S. Schroeder, Washington, D.C. page $298 \mathrm{~A}$

2. THE SPECTRUM OF BLOOD PRESSURE ELEVATION IN THE YOUNG ADULT POPULATION: THE UNRECOGNIZED MAGNITUDE OF THE PROBLEM. A.F. Salel, C. Lykke, ${ }^{*}$ C.K. Clifford, ${ }^{*}$ J. Kraus,* T.Y. Cooper,* N.O. Borhani,** and D.T. Mason, ** Davis, California. page $249 \mathrm{~A}$

3. DECISION ANALYSIS IN ESTIMATING PROBABILITIES OF IRON AND VITAMIN DEFICIENCY STATES IN ANEMIC PATIENTS. P. Oranburg* and P.F. Griner, ** Rochester, New York. page 248A

4. PREDICTION OF DEATH AND BACTERIAL INFECTION DURING HOSPITALIZATION USING TOTAL AND DIFFERENTIAL WHITE BLOOD CELL COUNTS, AGE, AND UNDERLYING DISEASE: DERIVATION OF OUTCOME-RELATED REFERENCE VALUES. I. Freeman and B.A. Rosner, Boston, Massachusetts. page $248 \mathrm{~A}$

5. POST TROHOC ERGO PROPTER TROHOC: PROBLEMS, CONFLICTING RESULTS, AND CRITERIA FOR SCIENTIFIC STANDARDS IN RETROSPECTIVE “CASE-CONTROL" RESEARCH. R.I. Horwitz* and A.R. Feinstein,** New Haven, Connecticut.

page $248 A$

6. A RANDOMIZED CONTROLLED STUDY OF THE EDUCATIONAL EFFECTS OF AN ALGORITHM SYSTEM. J.H. Wasson,* H.C. Sox, Jr.,* and R.D. Garcia* (Intr. by H.R. Holman), Stanford, California.

page $301 \mathrm{~A}$

7. EXERCISE ELECTROCARDIOGRAPHY AS A SCREENING PROCEDURE FOR CORONARY AR-
TERY DISEASE: PREVALENCE OF ISCHEMIC RESPONSE, ASSOCIATION WITH CORONARY RISK FACTORS AND RELATION TO PROGNOSIS. E.A. Amsterdam, J.H. Wilmore, * J. Davis,* A. DeMaria, and D.T. Mason, ** Davis, California.

page $248 A$

8. "SOCIOECONOMIC STATUS" AND REFERRAL BIAS IN CANCER MORTALITY. C.K. Wells* and A.R. Feinstein, New Haven, Connecticut. page $250 A$

$$
\text { Symposium }
$$

"Bench Research for Primary Care: Fact or Fantasy?"

Moderators: Thomas L. Delbanco and John Noble Participants:

1. TEACHING PRIMARY CARE-THE STAGE IS SET. Thomas L. Delbanco, Harvard University, Boston, Massachusetts.

2. SERIAL BIOPSIES OF THE PRACTICES AND HABITS OF MEDICAL HOUSE OFFICERS AND PRACTICING PRIMARY CARE INTERNISTS. Carl B. Lyle, David S. Citron, and William Applegate, University of North Carolina, Charlotte, North Carolina.

3. EVALUATION METHODS USED BY PATIENTS. Robert S. Lawrence, Harvard University, Boston, Massachusetts.

4. A FAMILY PHYSICIAN LOOKS AT THE EPIDEMIOLOGY OF ANGINA PECTORIS. Jack H. Medalie, Case Western Reserve University, Cleveland, Ohio.

5. THE DIMENSIONS OF CLINICAL INVESTIGATION IN PRIMARY CARE. John Noble, University of North Carolina, Chapel Hill, North Carolina.
Ballroom, Sheraton Seaside 7:00 P.M.

T.K. Li and Jack Metcoff, Presiding

1. INFLUENCE OF TYPE OF CARBOHYDRATE ON THE TRIGLYCERIDE RESPONSE TO HIGH CARBOHYDRATE DIETS IN DIABETIC MEN. J.W. Anderson, Lexington, Kentucky. ASCN page $498 A$

2. INCREASED PLASMA TRIIODOTHYRONINE AND CALORIC INEFFICIENCY IN EXPERIMENTAL PROTEIN MALNUTRITION. O.L. Tulp,* E.S. Horton, ${ }^{* *}$ E.D. Tyzbir, ${ }^{*}$ E. Danforth, Jr., and
J. Bollinger,* Burlington, Vermont, and Boston, Massachusetts. AFCR page $371 \mathrm{~A}$

3. MILK INTOLERANCE IN ALCOHOLICS. W. Perlow, ${ }^{*}$ E. Baraona,* and C.S. Lieber, Bronx and New York, New York. ASCN page $503 \mathrm{~A}$

4. PROTEIN-CALORIE MALNUTRITION IN A MAYAN COMMUNITY: EFFECTS ON NEUTROPHIL FUNCTION AT BIRTH. G.T. Keusch,* J.J. Urrutia, * R. Fernandez, ${ }^{*}$ and I.B. Kovacs* (Intr. by R. Zalusky**), New York, New York, and Guatemala City, Guatemala.
AFCR page 298 A 
5. MATERNAL NUTRITION AND LEUKOCYTE METABOLISM AT MIDPREGNANCY RELATED TO BABY/PLACENTAL SIZE AT TERM. J. Metcoff, M. Mameesh, ${ }^{*}$ G. Jacobson, ${ }^{*}$ P. Costiloe, ${ }^{*}$ W. Crosby,* H. Sandstead, and P. McClain, Oklahoma City, Oklahoma; Grand Forks, North Dakota; and Beltsville, Maryland. ASCN page $502 \mathrm{~A}$

6. IRON DEPOSITION IN THE HEART: EVALUATION BY ECHOCARDIOGRAPHY. W.L. Henry, A.W. Nienhuis, V.C. Canale, and M. Weiner, ${ }^{*}$ Bethesda, Maryland, and New York, New York.

AFCR page $222 A$
7. RAT PLASMA PREALBUMIN: CHARACTERIZATION AND NUTRITIONAL REGULATION. M. Navab,* A.K. Mallia, ${ }^{*}$ and D.S. Goodman, New York, New York.

ASCN page $503 \mathrm{~A}$

8. INHIBITION OF INTESTINAL IRON ABSORPTION BY LAUNDRY STARCH. F.B. Thomas, J.M. Falko,* and K. Zuckerman, * Columbus, Ohio.

AFCR page $292 \mathrm{~A}$

\section{Rutland Room, Haddon Hall 7:00 P.M.}

Laurence S. Jacobs and Peter Kohler, Presiding

1. DDAVP (1-DESAMINO-8-D-ARGININE-VASOPRESSIN)-KINETICS OF PROLONGED ANTIDIURESIS IN CENTRAL DIABETES INSIPIDUS. A.G. Robinson, S.M. Seif, F.F. Ciarochi,* T.V. Zenser, and B.B. Davis, Pittsburgh, Pennsylvania.

page $277 \mathrm{~A}$

2. ANTIDIURETIC MECHANISM OF ISOPROTERENOL. S.K. Webster and N. Beck, ** Pittsburgh, Pennsylvania, and San Antonio, Texas. page $280 \mathrm{~A}$

3. DISSOCIATION OF PLASMA AND CEREBROSPINAL FLUID PROLACTIN HETEROGENEITY. R.M. Jordan* and J.W. Kendall, ** Portland, Oregon. page $273 A$

4. PARTIAL CHARACTERIZATION OF AN AMNIOTIC FLUID PROTEIN REACTIVE WITH SOMATOMEDIN RECEPTORS. R.H. Chochinov,* I.K. Mariz,* and W.H. Daughaday, ${ }^{* *}$ St. Louis, Missouri. page $270 \mathrm{~A}$

5. IDENTIFICATION OF A GROWTH PEPTIDE RECEPTOR IN CULTURED HUMAN FIBROBLASTS. M.M. Rechler, S.P. Nissley, J.M. Podskalny,* A.C. Moses,* and L. Fryklund,* Bethesda, Maryland, and Stockholm, Sweden.

page $276 \mathrm{~A}$

6. A PROTAMINE LIGAND EXCHANGE ASSAY FOR NUCLEAR BOUND ESTROGEN RECEPTOR. D.T. Zava, ${ }^{*}$ N. Harrington, * and W.L. McGuire, San Antonio, Texas.

page $281 \mathrm{~A}$

7. "BIG" BIOACTIVE AND IMMUNOREACTIVE " $\beta$-MELANOCYTE STIMULATING HORMONES
IN HUMAN PLASMA, PITUITARY AND TUMOR TISSUE. K. Tanaka, * C.D. Mount,* W.E. Nicholson, ${ }^{* *}$ and D.N. Orth, ${ }^{* *}$ Nashville, Tennessee.

page $279 A$

8. GONADOTROPIN-RELEASING HORMONE STIMULATES HUMAN CHORIONIC GONADOTROPIN RELEASE IN TROPHOBLASTIC DISEASE. C. Macaron,* N. Freinkel, ** J. Brewer,* J.F. Wilber, B. Kahan, and B. Halpern, ${ }^{*}$ Chicago, Illinois. page $274 \mathrm{~A}$

\section{Symposium}

\author{
"Hypothalmic Hormones: \\ New Central Nervous System \\ Loci and New Functions"
}

Moderator: John F. Wilber

Participants:

1. PRESENCE AND DISTRIBUTION OF HYPOTHALAMIC PEPTIDES IN THE CENTRAL NERVOUS SYSTEM. Michael J. Brownstein, National Institutes of Health, Bethesda, Maryland.

2. THYROTROPIN RELEASING HORMONE BINDING TO SPECIFIC CENTRAL NERVOUS SYSTEM MEMBRANE RECEPTORS. David R. Burt, Johns Hopkins University, Baltimore, Maryland.

3. HYPOTHALAMIC PEPTIDE ACTIONS UPON SINGLE RAT NEURONS USING MICROIONTOPHORESIS. Leo Renaud, Montreal General Hospital, Montreal, Quebec. 
Pennsylvania Room II, Haddon Hall 7:00 P.M.

William Admirand and Jon Isenberg, Presiding

1. DIRECT DEMONSTRATION OF GASTRIN SYNTHESIS BY ANTRAL MUCOSAL EXPLANTS IN ORGAN CULTURE. R.F. Harty," J.C. Van der Vijver,* and J.E. McGuigan,** Gainesville, Florida. page $285 \mathrm{~A}$

2. DIARRHEIC FACTORS IN NON- $\beta$ ISLET CELL TUMOR OF THE PANCREAS. H.H. Tai,* W.Y. Chey,"* R. Escoffery," and J. Hendricks, ${ }^{*}$ Rochester, New York. page $292 \mathrm{~A}$

3. LITHIUM INHIBITS INTESTINAL ION SECRETION. J. Dobbins* and H.J. Binder, New Haven, Connecticut.

page $283 \mathrm{~A}$

4. THE MOTILITY COMPONENT OF CHOLERA: A PROSTAGLANDIN $F_{2} \alpha$ RESPONSE. J.R. Mathias* and J.L. Martin* (Intr. by P.P. Toskes), Gainesville, Florida.

page $289 \mathrm{~A}$

5. RELATIONSHIP OF ABDOMINAL AND CERVICAL VAGAL ACTIVITY ON LOWER ESOPHAGEAL SPHINCTER FUNCTION. S. Matarazzo,* W. Snape, Jr., J. Ryan,* and S. Cohen, Philadelphia, Pennsylvania. page $288 \mathrm{~A}$

6. EFFECT OF PROGRESSIVE SYSTEMIC SCLEROSIS ON ELECTRICAL AND MOTOR ACTIVITY
OF THE INTERNAL ANAL SPHINCTER. M. Cerulli,* P. Nikoomanesh, and M.M. Schuster, Baltimore, Maryland. page $282 \mathrm{~A}$

7. EFFECT OF CATECHOLAMINE DEPLETION ON OPOSSUM ESOPHAGEAL SMOOTH MUSCLE. D. de Carle,* M. Brody, and J. Christensen, Iowa City, Iowa. page $283 \mathrm{~A}$

8. EFFECTS OF INTRA-ARTERIAL UROKINASE INFUSION ON BLOOD FLOW, CLOTTING, AND FIBRINOLYSIS IN A CANINE MODEL OF SUPERIOR MESENTERIC ARTERIAL THROMBOSIS. N.J. Gurll, W. Callahan, II,* and H.V. Hufnagel, Washington, D.C.

page $285 A$

9. UROGASTRONE AND EPIDERMAL GROWTH FACTOR SHARE A COMMON RECEPTOR IN CULTURED HUMAN FIBROBLASTS. M.D. Hollenberg and $H$. Gregory,* Baltimore, Maryland, and Macclesfield, United Kingdom. page $286 \mathrm{~A}$

10. THE ROLE OF LUMINAL CONTENTS IN INTESTINAL ADAPTATION. D.M. MoCarthy, J.A. Nicholson,* and Y.S. Kim,** San Francisco, California.

page $289 \mathrm{~A}$

11. SPECIES DIFFERENCES IN PASSIVE ABSORPTION FROM THE SMALL INTESTINE. J.H. Bond, A.B. Micflikier, ${ }^{*}$ and M.D. Levitt, Minneapolis, Minnesota.

page $281 \mathrm{~A}$
Windsor Room, Haddon Hall 7:00 P.M. Robert Allen and Martin Cline, Presiding

1. DIPHENYLHYDANTOIN-INDUCED NEUTROPENIA: IN VITRO EVIDENCE FOR A DIRECT TOXIC EFFECT ON MARROW PRECURSOR CELLS. J.H. Fitchen, G.C. Bagby,* and J.W. Linman, ${ }^{* *}$ Portland, Oregon.

page $307 A$

2. INDUCTION OF SPLENIC LEUKOPOIESIS. D.W. Golde and M.J. Cline, ${ }^{* *}$ Los Angeles, California. page $309 \mathrm{~A}$

3. THE ISOLATION AND CHARACTERIZATION OF A COLONY STIMULATING FACTOR FROM HUMAN LUNG. S.S. Fojo,* M.C. Wu,* M.A. Gross, ${ }^{*}$ and A.A. Yunis, Miami, Florida. page $307 A$

4. LACTOFERRIN-A PROTEIN MARKER FOR NEUTROPHILS. R.M. Bennett and T. Kokocinski, * Chicago, Illinois.

page $303 \mathrm{~A}$
5. DISSIMILARITY OF IN VITRO COLONYFORMING CELLS AND ERYTHROCYTEENHANCED COLONY-FORMING CELLS. M.A. Kolitsky* and P.A. Chervenick, ${ }^{* *}$ Pittsburgh, Pennsylvania.

page $312 \mathrm{~A}$

6. VISUALIZING THE MARROW GRANULOCYTE RESERVE. R.A. Joyce and D.R. Boggs, Pittsburgh, Pennsylvania. page $312 \mathrm{~A}$

7. EFFECT OF CYTOCHALASIN B AND COLCHICINE ON HUMAN MONOCYTE FUNCTION. J. Rinehart* and T. Boulware* (Intr. by R. MacDermott), Washington, D.C., and Kansas City, Missouri. page $317 A$

8. EFFECT OF C3b INACTIVATOR ON MACROPHAGE BOUND C3b COATED ERYTHROCYTES. A.D. Schreiber and P. McDermott,* Philadelphia, Pennsylvania. page $319 A$ 
National Blood Club

9:00 P.M.

"The Red Cell Membrane"

Moderator: Wendell F. Rosse

Participants:

1. THE MOLECULAR ARRANGEMENT OF PROTEINS IN THE RED CELL MEMBRANE. Vincent Marchesi, Yale University, New Haven, Connecticut.

2. THE RED CELL MEMBRANE: DEFORMABILITY, FRAGMENTATION, AND HEMOLYSIS. Evan A. Evans, Duke University, Durham, North Carolina.
3. FLUID PROPERTIES OF SURFACE MEMBRANES: BIOPHYSICAL CLINICAL CORRELATES. Richard Cooper, University of Pennsylvania, Philadelphia, Pennsylvania.

4. THE CONSEQUENCE OF MEMBRANE CHANGES. Marcel Bessis, Paris, France.

\section{Immunology and Connective Tissue I}

\section{Pennsylvania Room I 7:00 P.M.}

Michael Frank and Daniel Stechschulte, Presiding

1. COMPLEMENT ACTIVATION BY ANTI-Rh ANTIBODY: EVIDENCE FOR BIOLOGIC FUNCTION VIA C3d. C.J. Jaffe,* J.P. Atkinson, M.H. McGinness, ${ }^{*}$ and M.M. Frank, Bethesda, Maryland.

page $330 \mathrm{~A}$

2. LUPUS BAND TEST: CORRELATION OF IMMUNOGLOBULIN CLASS DEPOSITION AND SERUM ANTIBODIES TO SINGLE STRANDED DEOXYRIBONUCLEIC ACID, AND OTHER NUCLEAR AND CYTOPLASMIC AUTOANTIGENS. T.T. Provost and M. Reichlin, Buffalo, New York. page 335A

3. SOLUBLE COMPLEXES IN SERA OF PATIENTS WITH GLOMERULONEPHRITIS: RELATIONSHIP TO AGE AND GLOMERULAR LOCALIZATION OF ANTIGLOBULIN. R.D. Rossen, M.A. Reisberg,* W.N. Suki, F.X. Schloeder, ${ }^{* *}$ L.L. Hill, ${ }^{* *}$ and G. Eknoyan, Houston, Texas. page $336 \mathrm{~A}$

4. QUANTITATION OF PRECIPITATING ANTIBODIES TO CERTAIN SOLUBLE NUCLEAR ANTIGENS IN SYSTEMIC LUPUS ERYTHEMATOSUS AND THEIR CONTRIBUTION TO HYPERGAMMAGLOBULINEMIA. P.J. Maddison* and M. Reichlin, Buffalo, New York.

page $332 A$

5. CLEARANCE OF IMMUNOSPECIFIC PARTICLES FROM THE CIRCULATION OF MAN: STUDIES IN PRIMARY BILIARY CIRRHOSIS, CHRONIC
ACTIVE HEPATITIS, AND ALCOHOLIC CIRRHOSIS. C.J. Jaffe, ${ }^{*}$ J.M. Vierling,* E.A. Jones, ${ }^{*}$ and M.M. Frank, Bethesda, Maryland. page $330 \mathrm{~A}$

6. UPTAKE OF INTRAVENOUSLY INFUSED PREFORMED IMMUNE COMPLEXES BY RENAL GLOMERULI AND RENAL NONGLOMERULAR TISSUE. L.A. Hebert, C.L. Allhiser, ${ }^{*}$ S.M. Koethe,* and G.E. Rodey, Milwaukee, Wisconsin. page $329 \mathrm{~A}$

7. LINKAGE OF FACTOR B, C2 DEFICIENCY, AND HLA, AND ORDERING OF GENES ON CHROMOSOME SIX. D. Raum,* D. Glass, * C.B. Carpenter,** C.A. Alper, ${ }^{* *}$ and P.H. Schur, ${ }^{* *}$ Boston, Massachusetts. page $335 \mathrm{~A}$

8. GENETIC, OPSONIC, AND BACTERICIDAL STUDIES IN A C2 DEFICIENT FAMILY. M.M. Glovsky,* G. Opelz,* and P.I. Terasaki* (Intr. by F.P. Quismorio), Los Angeles, California. page 327A

9. COMPLEMENT-MEDIATED ULTRASTRUCTURAL MEMBRANE LESIONS; REQUIREMENT FOR TERMINAL COMPONENTS. C.H. Packman,* S.I. Rosenfeld,* R.I. Weed,** and J.P. Leddy,** Rochester, New York.

page $334 \mathrm{~A}$

10. C2 AUGMENTATION OF THE C3 ACTIVATING FACTOR OF PARTIAL LIPODYSTROPHY. R.H. McLean* and S. Nilson* (Intr. by L. Hoyer), Farmington, Connecticut. page $332 A$ 


\section{Exhibit Hall \\ 7:00-9:00 P.M.}

1. THE INFLAMMATORY RESPONSE AND RESISTANCE TO ENDOTOXIN (LPS) IN MICE. G. Moeller, ${ }^{*}$ L. Terry,* J. Hunter, ${ }^{*}$ and R. Snyderman, Durham, North Carolina. page $333 A$

2. SOLID PHASE RADIOIMMUNOASSAY FOR DETECTION OF SERUM AUTOANTIBODIES IN SYSTEMIC LUPUS ERYTHEMATOSUS. K.O. Smith,* J.T. Harrington, Jr., and W.D. Gehle, * San Antonio, Texas.

page $336 \mathrm{~A}$

3. FALSE POSITIVE "NATIVE-DEOXYRIBONUCLEIC ACID" BINDING BY NON-SYSTEMIC LUPUS ERYTHEMATOSUS SERA. M.E. Medof, J. Locker,* R.M. Bennett, S. Sukhupunyaraksa,* and M. Hausknecht, ${ }^{*}$ Chicago, Illinois. page $332 A$

4. CYTOTOXIC ANTIBODIES BEFORE AND AFTER RENAL TRANSPLANTATION: CORRELATION OF GRAFT SUCCESS. J.J. Curtis,* W.V. Miller, B.A. Lucas, and R.G. Luke, Lexington, Kentucky. page $326 \mathrm{~A}$

5. IMPAIRED B LYMPHOCYTE ACTIVITY IN SYSTEMIC LUPUS ERYTHEMATOSUS. A.M. Bobrove and P. Miller,* Farmington and Newington, Connecticut. page $325 A$

6. THE EFFECTS OF IMMUNOSUPPRESSANTS ON T AND B LYMPHOCYTES. A. Winkelstein, Pittsburgh, Pennsylvania. page $338 \mathrm{~A}$

7. COMMON HLA-D ANTIGEN IN PATIENTS WITH PROGRESSIVE SYSTEMIC SCLEROSIS. A.G. DiBartolomeo,* B.S. Rabin,* and G.P. Rodnan** (Intr. by E.B. Flink), Morgantown, West Virginia, and Pittsburgh, Pennsylvania. page $326 \mathrm{~A}$

8. EMERGENCE OF INSULIN RECEPTORS UPON ALLOIMMUNE T CELLS. T.B. Strom, J.H. Helderman, M.D. Hollenberg, and C.B. Carpenter,** Boston, Massachusetts, and Baltimore, Maryland. page $337 A$

9. HUMAN ANTIBODY-DEPENDENT CELLULAR CYTOTOXICITY: DIFFERENTIAL INTERACTION WITH EFFECTOR CELL POPULATIONS
BY HOMOLOGOUS AND HETEROLOGOUS ANTIBODY. S.R. Kanner, ${ }^{*}$ M.A. Bookman, ${ }^{*}$ and D.M. Bull, ** Boston, Massachusetts. page $330 \mathrm{~A}$

10. SALIVARY SECRETORY COMPONENT DEFICIENCY AND FIBRINOLYTIC SYSTEM ABNORMALITY IN BEHCET'S DISEASE. N.I. Abdou, J. Hebert,* E. Pascual,* E.T. Carroll,* H.R. Schumacher, M. Miller, ${ }^{*}$ R.W. Colman, and M.A. South, Kansas City, Kansas, and Philadelphia, Pennsylvania. page $324 \mathrm{~A}$

11. LYMPHOTOXIN SECRETION IN VITRO AS A MEASURE OF IMMUNOCOMPETENCE IN CANCER PATIENTS: A POSSIBLE CORRELATION WITH PROGNOSIS. J.A. Stratton* and P.E. Byfield (Intr. by L. Sieger), Torrance, California.

page $337 A$

12. LYMPHOCYTE REACTIVITY IN UNTREATED PATIENTS WITH CHRONIC LYMPHOCYTIC LEUKEMIA: ABILITY OF T CELL ENRICHED FRACTIONS TO RESPOND TO ALLOGENEIC AND AUTOLOGOUS B CELL ENRICHED FRACTIONS. J.B. Smith, R. Knowlton,* and L.S. Koons, * Philadelphia, Pennsylvania. page $336 A$

13. MODIFICATION OF RESPONSES OF HUMAN NEUTROPHILS TO MONOSODIUM URATE CRYSTALS BY COATING OF CRYSTALS WITH SERUM PROTEINS. F. Kozin, ${ }^{*}$ J.L. Skosey, J. May,* and D.C. Chow, ${ }^{*}$ Milwaukee, Wisconsin, and Chicago, Illinois. page $331 \mathrm{~A}$

14. INDUCTION OF ARTHRITIS IN RABBITS BY PURIFIED CELL DERIVED CHEMOTACTIC FACTOR: ROLE OF CHEMOTAXIS AND VASCULAR PERMEABILITY. I. Spilberg, D. Rosenberg, ${ }^{*}$ and B. Mandell,* St. Louis, Missouri. page $337 A$

15. MONOCYTES IN INFLAMMATION: ELABORATION OF TOXIC OXYGEN BYPRODUCTS IN A MODEL OF IMMUNE COMPLEX DISEASE. R.B. Johnston, Jr., J.E. Lehmeyer, ${ }^{*}$ and L.A. Guthrie, ${ }^{*}$ Birmingham, Alabama. 
Pennsylvania Room III, Haddon Hall

7:00 P.M.

Sherwood Gorbach and

Charles Smith, Presiding

1. SERUM IMMUNOGLOBULIN A AND SUSCEPTIBILITY TO MFNINGOCOCCAL DISEASE. J.M. Griffiss and M.A. Bertram, ${ }^{*}$ Washington, D.C.

page $344 A$

2. ACUTE DIARRHEA IN U.S. STUDENTS ATTENDING A MEXICAN UNIVERSITY. H. DuPont, J. Olarte, ${ }^{*}$ D. G. Evans, ${ }^{*}$ L. Pickering, G. Haynes, ${ }^{*}$ B. Portnoy,* D.J. Evans, Jr., ${ }^{*}$ and R. Conklin,* Houston, Texas, and Mexico City, Mexico. page $342 \mathrm{~A}$

3. CHEMILUMINESCENCE BY GRANULOCYTES: ROLE OF MYELOPEROXIDASE, SINGLET OXYGEN AND SUPEROXIDE ANION. H. Rosen* and S.J. Klebanoff, ${ }^{* *}$ Seattle, Washington. page $353 \mathrm{~A}$

4. THE SELECTIVE MOBILIZATION OF SPECIFIC GRANULES BY HUMAN NEUTROPHILS DURING ADHERENCE IN VITRO AND DURING EXUDATION IN VIVO. D.G. Wright and J.I. Gallin, Bethesda, Maryland. page $355 \mathrm{~A}$

5. THE EFFECT OF SPLENECTOMY ON PHAGOCYTOSIS OF STREPTOCOCCUS PNEUMONIAE TYPE II IN INFANT SPRAGUE-DAWLEY RATS AND THE INFLUENCE OF PNEUMOCOCCAL VACCINE IN THIS SYSTEM. A.J. Provisor,* J.M. Allen, ${ }^{*}$ and R.L. Baehner, ${ }^{* *}$ Indianapolis, Indiana. page $351 \mathrm{~A}$

6. CELL-MEDIATED CYTOTOXICITY IN MUCOCUTANEOUS INFECTIONS WITH HERPES SIMPLEX VIRUS, TYPES 1 AND 2. R. Reichman,* R. Dolin, M. Vincent,* and A.S. Fauci, Bethesda, Maryland.

page $352 A$
7. INTERFERON MOLECULES IN HUMAN BIOLOGICAL FLUIDS: RELATION OF THEIR STRUCTURAL CHARACTERISTICS TO THEIR CELlULAR SOURCE. G.E. Panagos, ${ }^{*}$ J.A. O’Malley, ${ }^{*}$ and W.A. Carter, Buffalo, New York.

page $351 \mathrm{~A}$

8. CROSS-REACTIVITY OF RABBIT ANTIBODIES TO STREPTOCOCCUS MUTANS WITH HUMAN HEART TISSUE AND THE SEROTYPE SPECIFIC ANTIGENS OF STREPTOCOCCUS MUTANS. R. Arnold,* J. McGhee,* and L. Robinson* (Intr. by J.C. Bennett), Birmingham, Alabama. page 339A

\section{Symposium}

"New Perspectives on Anaerobes"

Moderator: Sherwood L. Gorbach

Participants:

1. LESSONS FROM AN ANIMAL MODEL OF ANAEROBIC INFECTIONS. John G. Bartlett, Tufts University, Boston, Massachusetts.

2. IMMUNOCHEMISTRY AND VIRULENCE OF BACTEROIDES FRAGILIS. Dennis Kasper, Channing Laboratory, Harvard Medical School, Boston, Massachusetts.

3. METABOLIC ACTIVITY OF ANAEROBES RELATING TO DRUGS AND CARCINOGENS. Peter Goldman, Harvard Medical School, Boston, Massachusetts. 


\section{Vernon Room, Haddon Hall 7:00 P.M.}

Mayer B. Davidson and Joseph L. Goldstein, Presiding

1. ACTIVATION OF PROTEIN KINASE IN RENAL CORTEX BY PARATHYROID HORMONE AND GLUCAGON: SPECIFICITY OF ENZYME TRANSLOCATION. P.A. Craven* and F.R. DeRubertis (Intr. by A.S. Blumentals), Pittsburgh, Pennsylvania. page $359 \mathrm{~A}$

2. DIFFERENCES IN PARATHYROID HORMONE METABOLISM BETWEEN LIVER AND KIDNEY. K. Martin,* K. Hruska, A. Greenwalt,* S. Klahr, and E. Slatopolsky, St. Louis, Missouri. page $365 \mathrm{~A}$

3. PROSTAGLANDIN MEDIATED HYPERCALCEMIA IN THE VX ${ }_{2}$ CARCINOMA-BEARING RABBIT. H.W. Seyberth, W.C. Hubbard,* J.L. Morgan,* B.J. Sweetman,* and J.A. Oates, Nashville, Tennessee. page $370 \mathrm{~A}$

4. SUCROSE POLYESTER: EFFECTS ON FECAL CHOLESTEROL, TOTAL NEUTRAL STEROL, AND FATTY ACIDS. R.W. Fallat, C.J. Glueck, F. Mattson,* T.T. Ishikawa,* and J. Brazier,* Cincinnati, Ohio.

page $360 \mathrm{~A}$

5. THE HEPATIC SECRETION OF APOPROTEINS A-I and B IN THE RAT. J.L. Witztum* and G. Schonfeld, St. Louis, Missouri. page $373 \mathrm{~A}$
6. HYPERTRIGLYCERIDEMIA IN HEMODIALYSIS PATIENTS: DUAL DEFECT OF ADIPOSE TISSUE LIPOPROTEIN LIPASE. A. Goldberg, D. Sherrard, and J. Brunzell, Seattle, Washington. page $361 \mathrm{~A}$

7. LOW DENSITY LIPOPROTEIN KINETICS IN TYPE IV AND TYPE V HYPERLIPOPROTEINEMIA. J.G. Brook, ${ }^{*}$ H.A. Feldman,* and R.S. Lees, Boston and Cambridge, Massachusetts.

page $357 \mathrm{~A}$

8. EFFECT OF POLYUNSATURATED VERSUS SATURATED FAT ON LOW DENSITY LIPOPRO TEIN METABOLISM IN NORMAL SUBJECTS. D. Yeshurun,* A.M. Gotto, Jr., and O.D. Taunton, Houston, Texas. page $373 A$

9. EFFECTS OF RAPID DEPLETION OF PLASMA PHENYLALANINE AND TYROSINE ON SLEEP AND BEHAVIOR. P.L. Poffenbarger, E.S. Barratt,* P.L. Adams, ${ }^{*}$ R.R. Fritz, ${ }^{*}$ and C.W. Abell,* Galveston, Texas.

page $367 A$

10. CYCLIC GUANOSINE MONOPHOSPHATE METABOLISM IN NEONATAL KIDNEY GROWTH. D. Schlondorff,* H. Weber, and W. Trizna,* Bronx, New York. page $369 A$

\section{Garden Room, Haddon Hall 7:00 P.M.}

\section{William Kremer and B.G. Leventhal, Presiding}

1. GLUCOCORTICOID RECEPTORS IN CHILDHOOD ACUTE LYMPHOCYTIC LEUKEMIA. G. Konior,* M. Lippman, G. Johnson, * and B. Leventhal, Bethesda, Maryland.

page $377 A$

2. BINDING OF BENZO(a)PYRENE METABOLITES TO DEOXYRIBONUCLEIC ACID IN VITRO CATALYZED BY HUMAN LYMPHOCYTES. A.R. Boobis,* D.W. Nebert, and S.A. Atlas,* Bethesda, Maryland.

page $374 A$

3. THE PATHOGENESIS OF METHOTREXATE NEPHROTOXICITY. S. Pitman* and E. Frei, III,** Boston, Massachusetts.

page $380 \mathrm{~A}$

4. GRANULOCYTE TRANSFUSIONS IN ACUTE LEUKEMIA. J.B. Alavi,* R.K. Root, A.E. Evans,* I. Djerassi,* D. Guerry,* A.D. Schreiber, J. Shaw, ${ }^{*}$ and R.A. Cooper, Philadelphia, Pennsylvania.

page $373 A$
5. INTRALESIONAL INJECTION OF METHANOL EXTRACTION RESIDUE OF BCG IN METASTATIC MELANOMA. S.E. Krown, * C.M. Pinsky, Y. Hirshaut, and H.F. Oettgen,** New York, New York.

page $377 A$

6. RANDOMIZED TRIAL OF PROPHYLACTIC VERSUS THERAPEUTIC PLATELET TRANSFUSION IN CHILDHOOD ACUTE LEUKEMIA. S. Murphy, P.A. Koch,* and A.E. Evans, ${ }^{*}$ Philadelphia, Pennsylvania.

page $379 A$

7. FETAL ANTIGENS IN CHRONIC LYMPHOCYTIC LEUKEMIA. A.K. Sullivan,* L.M. Jerry, and M.G. Lewis, Montreal, Quebec, Canada. page 381A

8. RETICULOENDOTHELIAL SCANS VERSUS BONE SCANS IN MALIGNANT DISEASES. D.P. Shreiner and Y. Hsu,* Pittsburgh, Pennsylvania.

page $381 \mathrm{~A}$ 
Teakwood Room, Lafayette

7:00 P.M.

Kaye Kilburn and John Weil, Presiding

1. ALTERATIONS OF SUPEROXIDE DISMUTASE BY STATE OF OXYGENATION IN MAMMALIAN SYSTEMS: L.M. Simon, J. Liu,* J. Theodore, and E.D. Robin,** Palo Alto, California. page $390 \mathrm{~A}$

2. REGULATION OF INTRACELLULAR $\mathrm{pH}$ IN RABBIT ALVEOLAR MACROPHAGES. D. Laman,* J. Theodore, and E.D. Robin, ${ }^{* *}$ Stanford, California. page $386 \mathrm{~A}$

3. ALTERATIONS IN FREE AIRWAY CELLS FOLLOWING EXPOSURE TO CADMIUM AEROSOL. S. Asvadi ${ }^{*}$ and J.A. Hayes, ${ }^{* *}$ Boston, Massachusetts. page $382 \mathrm{~A}$

4. PROPERTIES OF ALVEOLAR ALPHA-1-ANTITRYPSIN IN MAN. J.O. Harris and J. Goldblatt,* Gainesville, Florida. page $385 \mathrm{~A}$

5. AMNIOTIC FLUID CORTISOL: RELATIONSHIP TO FETAL LUNG MATURATION. I.H. Gewolb, J.C. Hobbins, ${ }^{*}$ and S.Y. Tan, New Haven, Connecticut. page $385 \mathrm{~A}$

6. PERIPHERAL PLASMA DETERMINATIONS OF PROSTAGLANDIN E IN ASTHMATICS. J. Allegra, J. Trautlein, L. Demers, ${ }^{*}$ J. Field,* and M. Gillin, Hershey, Pennsylvania.

page $382 A$

7. IN VIVO ALVEOLAR CAPILLARY MEMBRANE PERMEABILITY CHANGES IN HEMORRHAGIC HYPOTENSION. F.L. Glauser, P. Fischer, ${ }^{*}$ and J.E. Millen, ${ }^{* *}$ Long Beach, California. page $385 \mathrm{~A}$
8. DIFFERENTIAL RESPONSE OF MALE AND FEMALE AIRWAY EPITHELIUM TO CHRONIC TOBACCO SMOKE INHALATION. M. Hayashi,* C. Sornberger, ${ }^{*}$ P. Phelps, ${ }^{*}$ and G. Huber, Boston, Massachusetts. page $386 \mathrm{~A}$

\section{Symposium}

"Clinical Measurement of Pulmonary Edema"

Moderator: W.G. Johanson, Jr.

Participants:

1. DETERMINATION OF LUNG THERMAL VOLUME BY THE DOUBLE INDICATOR DILUTION TECHNIQUE. Nicholas E. O'Connor, Harvard Medical School, Boston, Massachusetts.

2. A REBREATHING TECHNIQUE FOR THE MEASUREMENT OF PULMONARY CAPILLARY BLOOD VOLUME, MEMBRANE DIFFUSING CAPACITY, PULMONARY TISSUE VOLUME, AND CARDIAC OUTPUT. Alan H. Morris, University of Utah, Salt Lake City, Utah.

3. MEASUREMENT OF ENDOTHELIAL INTEGRITY IN THE LUNG. Arnold B. Gorin, University of California, Davis, California.

\section{Viking Room, Haddon Hall} 7:00 P.M.

Saulo Klahr and Franklin Knox, Presiding

1. ACTIVATION OF CYCLIC ADENOSINE MONOPHOSPHATE SYSTEM AND PROTEIN KINASE BY PARATHYROID HORMONE AND CALCITONIN WITHOUT PHOSPHATURIA IN HAMSTER. T.P. Dousa, J. Preiss, ${ }^{*}$ J.K. Kim, Y.S.F. Hui, ${ }^{*}$ and F.G. Knox, Rochester, Minnesota. page 399A

2. CHRONIC PHOSPHATE DEPLETION: PROXIMAL TUBULAR FUNCTION AND HYPERCALCIURIA. S. Goldfarb, G.R. Westby, ${ }^{*}$ M. Goldberg, and Z.S. Agus, Philadelphia, Pennsylvania. page 401A

3. EVIDENCE FOR PARATHYROID HORMONE ENHANCEMENT OF CALCIUM AND MAGNESIUM
REABSORPTION IN THE TERMINAL NEPHRON SEGMENT OF THE HAMSTER. C.A. Harris, ${ }^{*} M$. Burnatowska, ${ }^{*}$ R.A.L. Sutton, and J.H. Dirks, ${ }^{* *}$ Montreal, Quebec, Canada.

page $401 A$

4. SATURATION KINETICS OF PHOSPHATE REABSORPTION: MICROPERFUSION STUDIES IN THE RENAL PROXIMAL TUBULE OF THE THYROPARATHYROIDECTOMIZED RAT. F. Lang,* R. Greger,* G. Marchand,* and F.G. Knox, Rochester, Minnesota. page $405 A$

5. MECHANISM OF PHOSPHATURIA DURING ACUTE HYPERCAPNIA. R.K. Webb, ${ }^{*}$ P.B. Woodhall,* C.C. Tisher, F.A. Neelon, ${ }^{*}$ and R.R. Robinson,** Durham, North Carolina. page 415A

1976 Programs $\cdot$ ASCI-AFCR-AAP xv 
6. DEFECT IN THE CELLULAR ACTION OF VASOPRESSIN IN HYPOTHYROIDISM AND ITS CORRECTION BY THYROXINE TREATMENT. T.M. Harkcom,* J.K. Kim, Y.S.F. Hui,* P.J. Palumbo,** and T.P. Dousa, Rochester, Minnesota. page $401 \mathrm{~A}$

7. DISSOCIATION OF PROXIMAL TUBULAR URATE AND SODIUM REABSORPTION IN THE RAT. E.J. Weinman, T. Knight, ${ }^{*}$ R. McKenzie, ${ }^{*}$ and G. Eknoyan, Houston, Texas. page $416 A$

8. MECHANISM OF URICOSURIA: STUDIES WITH TICRYNAFEN (SKF 62698). K. Lau, ${ }^{*}$ R. Stote, M. Goldberg, ${ }^{* *}$ and Z.S. Agus, Philadelphia, Pennsylvania.

page $405 A$
9. DEOXYCORTICOSTERONE ACETATE DOES NOT STIMULATE RENAL NA-K-ADENOSINE TRIPHOSPHATASE IN SALT-DEPLETED, CHRONICALLY ADRENALECTOMIZED RATS. C. Westenfelder, G. Arevalo, * R.L. Baranowski, N.A. Kurtzman, and A.I. Katz,** Chicago, Illinois.

page $416 \mathrm{~A}$

10. THE EFFECT OF $\mathrm{K}^{+}$LOADING ON $\mathrm{NH}_{3}$ PRODUCTION BY CORTEX AND OUTER MEDULLA. R.L. Tannen, Burlington, Vermont. page 413A

\author{
West Room, Haddon Hall \\ 7:00 P.M. \\ John Hayslett and C. Craig Tisher, \\ Presiding
}

1. URINARY PRECESSION OF URATE FROM INULIN AS AN INDEX OF URATE SECRETION. E.J. Weinman, D. Steplock, ${ }^{*}$ and G. Eknoyan, Houston, Texas.

page $416 \mathrm{~A}$

2. ROLE OF INTRACELLULAR CALCIUM ON BASELINE AND ANTIDIURETIC HORMONE STIMULATED SODIUM TRANSPORT IN THE TOAD BLADDER. W. Wiesmann,* S. Sinha,* and S. Klahr, St. Louis, Missouri. page $416 A$

3. EVIDENCE FOR ENHANCED URINARY ACIDIFICATION BY CARBONIC ACID BACKDIFFUSION. J. Schwartz, Washington, D.C. page $411 A$

4. EFFECTS OF LITHIUM ON PROXIMAL AND Distal TUBULAR FUNCTION. B. Hecht,* $M$. Kashgarian,* J.N. Forrest, and J.P. Hayslett, New Haven, Connecticut. page $402 A$

5. IMPORTANCE OF BICARBONATE TO THE PARATHYROID HORMONE-INDUCED CHANGES OF FLUID ABSORPTION BY THE PROXIMAL TUBULE. V.W. Dennis and R.R. Robinson,** Durham, North Carolina.

page $397 A$
6. INHIBITION OF ANTIDIURETIC HORMONEINDUCED WATER FLOW IN THE TOAD URINARY BLADDER BY TETRACYCLINES: CORRELATION OF PHYSIOLOGICAL EFFECT WITH EPITHELIAL CELL PROTEIN BINDING. M. Cox and I. Singer, Philadelphia, Pennsylvania. page $397 A$

7. RENAL BICARBONATE REABSORPTION BY THE HYPOTHYROID RAT. U.F. Michael, J. Kelley* and C.A. Vaamonde, ${ }^{* *}$ Miami, Florida.

page $407 A$

8. AN EXAMINATION OF THE TUBULO-GLOMERULAR FEEDBACK HYPOTHESIS. R.C. Blantz and K.S. Konnen, * La Jolla, California. page $393 A$

9. PERMEABILITY OF THE RENAL PAPILLARY EPITHELIUM AND URINARY CONCENTRATING ABILITY. C. Lechene, ${ }^{* *}$ J.V. Bonventre, ${ }^{*}$ and M.J. Karnovsky,* Boston, Massachusetts. page 405A

10. PATHOGENESIS OF HYPERGLUCAGONEMIA IN THE UREMIC RAT. D.S. Emmanouel, J.B. Jaspan," S.F. Kuku,* A.H. Rubenstein, and A.I. Katz,** Chicago, Illinois. page 399A 
Program-Subspecialty Meetings

Jointly Sponsored by

THE AMERICAN FEDERATION FOR CLINICAL RESEARCH, THE AMERICAN SOCIETY FOR CLINICAL INVESTIGATION

and

\section{THE ASSOCIATION OF AMERICAN PHYSICIANS}

Chalfonte-Haddon Hall, LaFayette Hotel, and Ramada Inn

Atlantic City, New Jersey

SUNDAY AFTERNOON, MAY 2, 1976

Cardiovascular, Pennsylvania Room II, Haddon Hall

Cardiovascular Poster Session, Exhibit Hall

Clinical Epidemiology and Health Care Research, Solarium, Haddon Hall

Clinical Pharmacology, Ramada Inn

Dermatology, Teakwood Room, LaFayette

Endocrinology, Pennsylvania Room III, Haddon Hall

Gastroenterology, Vernon Room, Haddon Hall
Genetics, Garden Room, Haddon Hall

Hematology, Windsor Room, Haddon Hall

Immunology, and Connective Tissue, Rutland Room, Haddon Hall

Infectious Disease, Viking Room, Haddon Hall

Metabolism, Pennsylvania Room I, Haddon Hall

Metabolism Poster Session. Exhibit Hall

Oncology, West Room Haddon Hall

Pulmonary, Music Room, Chalfonte

Renal and Electrolyte, Carolina Room, Chalfonte

Cardiovascular

Pennsylvania Room II, Haddon Hall

1:30 P.M.

J. Thomas Bigger and William B. Hood, Presiding

1. MYOGLOBINEMIA AS A CLUE TO THE PRESENCE OF ACUTE MYOCARDIAL INFARCTION. J.T. Willerson, ${ }^{*}$ L. Poliner, ${ }^{*}$ L.M. Buja, ${ }^{*}$ M.R. Waterman,* C.E. Gomez-Sanchez, ${ }^{*}$ G.H. Templeton* and M.J. Stone* (Intr. by D.W. Foster), Dallas, Texas.

ASCI page 422A

2. HEMODYNAMIC IMPROVEMENT WITH HYDRALAZINE IN LEFT HEART FAILURE. J.A. Franciosa and J.N. Cohn, ${ }^{* *}$ Minneapolis, Minnesota. AFCR page 217 A

3. REGIONAL SYMPATHETIC ACTIVITY IN RIGHT HEART FAILURE: CHOLINE ACETYLTRANS-
FERASE ACTIVITY IN GANGLIA AND NOREPINEPHRINE TURNOVER RATE IN THE HEART AND VASCULATURE. P.G. Schmid* and R. Roskoski, Jr.* (Intr. by F.M. Abboud), lowa City, Iowa.

ASCI page $421 \mathrm{~A}$

4. DETECTION OF MYOCARDIAL ISCHEMIA BY COMPUTERIZED TOMOGRAPHY IN CANINE HEARTS. W.J. Powell, Jr., J. Wittenberg,* R.E. Dinsmore,* S.W. Miller, * and R.A. Maturi,* Boston, Massachusetts. ASCI page $420 \mathrm{~A}$

5. RELATIVE EFFECTS OF NITROPRUSSIDE AND NITROGLYCERIN ON ISCHEMIA AFTER EXPERIMENTAL CORONARY OCCLUSION. R.L. Engler,* A.S. Pearlman,* R.A. Goldstein,* K.M. Kent, and S.E. Epstein, Bethesda, Maryland.

AFCR page $216 A$ 
6. EFFECTS OF ISOPROTERENOL ON REGIONAL MYOCARDIAL FUNCTION, ELECTROGRAM AND BLOOD FLOW IN CONSCIOUS DOGS WITH MYOCARDIAL ISCHEMIA. S.F. Vatner, R.W. Millard, T.A. Patrick, ${ }^{*}$ and G.R. Heyndrickx, ${ }^{*}$ Boston, Massachusetts. AFCR page $243 A$

7. IDENTIFYING ANGIOTENSIN-DEPENDENT HYPERTENSION: A COMPARISON OF TWO DIFFERENT ANGIOTENSIN INHIBITORS AND RENIN PROFILING. D.B. Case,* J.M. Wallace,* H.J. Keim,* J.E. Sealey,* and J.H. Laragh,** New York, New York. ASCI page $418 \mathrm{~A}$

8. CHRONIC LABILE NEUROGENIC HYPERTENSION PRODUCED BY SMALL LESIONS OF BRAIN. M.A. Nathan and D.J. Reis, New York, New York. ASCI page $420 A$

9. LOW RENAL PAPILLARY PLASMA FLOW IN BOTH DAHL AND KYOTO SPONTANEOUS HYPERTENSIONS. L. Tobian, ** M. Ganguli, and L. Dahl, Minneapolis, Minnesota, and Upton, New York.

AAP page $474 A$
10. EXTERNAL QUANTIFICATION OF MYOCARDIAL INFARCTION IN VIVO. E.S. Weiss,* M.J. Welch,* M.M. Ter-Pogossian,* and B.E. Sobel, St. Louis, Missouri. ASCI page $422 A$

11. EFFECTS OF ETHANOL ON VENTRICULAR ELECTRICAL STABILITY IN THE CHRONIC ALCOHOLIC ANIMAL. C.L. De La Cruz, Jr., ${ }^{*}$ B. Haider,* P.O. Ettinger,* and T.J. Regan,** Newark, New Jersey. ASCI page $419 A$

12. THE EFFECT OF ANOMALOUS PATHWAY LOCATION ON RATE OF EXPERIMENTAL ATRIOVENTRICULAR REENTRANT TACHYCARDIA IN THE DOG. P. Denes,* F. Amat-y-Leon,* S. Teague,* A. Blasdell,* and K. Rosen, Chicago, Illinois.

ASCI page 419A

13. ELECTROPHYSIOLOGIC, ECHOCARDIOGRAPHIC AND HEMODYNAMIC CORRELATIONS OF LEFT ATRIAL ENLARGEMENT. M.E. Josephson,* J. Morganroth,* and J.A. Kastor,** Philadelphia, Pennsylvania. AAP page 472A

\section{Exhibit Hall \\ 1:00-3:00 P.M.}

1. TOMOGRAPHIC MYOCARDIAL PERFUSION IMAGING USING A DOUBLE CAMERA COINCIDENCE SYSTEM. W. Walsh, ${ }^{*}$ H. Fill,* M. Buchin,* G. Muellehner, ${ }^{*}$ F. Atkins, ${ }^{*}$ P. Harper, ${ }^{*}$ and L. Resnekov** (Intr. by H. Brooks**), Chicago, Illinois.

page $244 A$

2. INTRAOPERATIVE ANALYSIS BY ECHOCARDIOGRAPHY OF OUTFLOW TRACT OBSTRUCTION IN TETRALOGY OF FALLOT. H.M. Spotnitz, J.R. Malm,* E. Krongrad,* D.L. King,* R.W. Pooley,* F.O. Bowman, Jr., ${ }^{*}$ R.N. Edie, ${ }^{*}$ and B.F. Hoffman,* New York, New York.

page $241 A$

3. ANATOMIC VALIDATION OF LEFT VENTRICULAR MASS DETERMINATION BY ECHOCARDIOGRAPHY IN MAN. R.B. Devereux, ${ }^{*}$ N. Reichek, and P.J. Klunder,* Philadelphia, Pennsylvania.

page $214 A$

4. DETECTION OF MYOCARDIAL DAMAGE WITH $99 \mathrm{~m}$ TC-PYROPHOSPHATE AFTER OPEN HEART SURGERY. I.S. Lowenthal,* A.F. Parisi, D.E. Tow, E.M. Barsamian, ${ }^{*}$ H.C. Clemson, ${ }^{*}$ and D. MCCaughan,* West Roxbury and Boston, Massachusetts.

page $228 \mathrm{~A}$

5. POST HOSPITAL FREQUENCY OF CARDIAC ARRHYTHMIAS FOLLOWING MYOCARDIAL INFARCTION RELATED TO THE LENGTH OF HOSPITALIZATION. M. Nejat and E. Greif,** Brooklyn, New York.

page $233 A$
6. ACUTE BLOOD PRESSURE ELEVATION AND VENTRICULAR FIBRILLATION THRESHOLD DURING CORONARY ARTERY OCCLUSION AND REPERFUSION IN THE DOG. C.M. Blatt,* R.L. Verrier,* and B. Lown,** Boston, Massachusetts. page $209 A$

7. LACK OF EFFECT OF LIDOCAINE ON NERVE DISCHARGE AND ARRHYTHMIA PRODUCED BY ACUTE CORONARY OCCLUSION. C.M. Lathers, ${ }^{*}$ J. Roberts, ${ }^{* *}$ and G.J. Kelliher, Philadelphia, Pennsylvania. page $226 \mathrm{~A}$

8. SEGMENTAL LEFT VENTRICULAR FUNCTION AND METABOLISM FOLLOWING REPERFUSION OF ACUTELY ISCHEMIC MYOCARDIUM. J.J. Kane,* M.L. Murphy,** C.F. Peng,* K.D. Straub,* J.K. Bissett, and J.E. Doherty, ${ }^{* *}$ Little Rock, Arkansas. page $224 A$

9. MYOCARDIAL FUNCTION AND RENIN IN THE SPONTANEOUSLY HYPERTENSIVE RAT AFTER CENTRAL AND PERIPHERAL SYMPATHECTOMY. A. Cutilletta, L. Erinoff,* and S. Oparil, Chicago, Illinois.

page $214 A$

10. CARNITINE-INDUCED EFFECTS ON CARDIAC AND PERIPHERAL HEMODYNAMICS. H.L. Brooks,** R. Holland, N. Sanzari,* S. DeFelice,* and L. Goldberg, ${ }^{* *}$ Chicago, Illinois, and New York, New York. page $211 \mathrm{~A}$

11. CREATINE PHOSPHOKINASE DISAPPEARANCE FOLLOWING ACUTE MYOCARDIAL INFARCTION. L. Reduto,* R. Pizzarello, ${ }^{*}$ K. Geller, ${ }^{*}$ S. Gulotta, and J. Morrison, Manhasset, New York.

page $237 A$ 
12. CARDIOVASCULAR FUNCTION DURING EARLY RECOVERY FROM ACUTE MYOCARDIAL INFARCTION. H.R. Lewis,* A.J. Wohl,* J.T. Willerson, C.B. Mullins, ${ }^{* *}$ and C.G. Blomqvist,** Dallas, Texas.

page $227 A$

13. VASODILATION AND THROMBOLYSIS WITH INTRA-ARTERIAL UROKINASE INFUSION IN THE CANINE FEMORAL CIRCULATION. N.J. Gurll, W. Callahan, II,* and H.V. Hufnagel, Washington, D.C.

page $219 A$
14. EARLY ADAPTATIONS TO SIMULATED ZERO GRAVITY. J.V. Nixon,* R.G. Murray,* O.B. Holland,* R.L. Johnson, Jr.,** P. Vergne-Marini,* and C.G. Blomqvist, ${ }^{* *}$ Dallas, Texas.

page $233 A$

15. POST EXTRASYSTOLIC COMPLIANCE OF THE LEFT VENTRICLE. W.H. Gaasch, O.H.L. Bing, J.S. Cole, and H.G. Hanley, Boston, Massachusetts, and Houston, Texas.

page $218 \mathrm{~A}$

\section{Clinical Epidemiolo

\author{
Solarium, Haddon Hall \\ 1:30 P.M. \\ Charles A. Sanders and Joseph C. Shipp, \\ Presiding
}

1. FACTORS AFFECTING PROBLEM FOLLOW-UP IN AMBULATORY CARE. D.W. Simborg* and B.H. Starfield* (Intr. by R.J. Johns**), Baltimore, Maryland.

AAP page $479 A$

2. EVALUATING PHYSICIAN EXTENDERS' MEDICAL CARE: ALGORITHM-ASSISTED MANAGEMENT OF AMBULATORY PATIENTS WITH ACUTE RESPIRATORY ILLNESSES. B.W. Wolcott,* R.W. Wood,* L.M. Burger,* and R.K. Tompkins, San Antonio, Texas, and Seattle, Washington. AFCR page $302 \mathrm{~A}$

3. CARDIAC REACTIVE ACCELERATION IN THE SURVEILLANCE OF FETAL WELL-BEING. F.G. Mariona** and G. Valookaren,* Detroit, Michigan. AAP page 479A

4. COMPUTERIZED TOMOGRAPHY VERSUS BRAIN SCANNING IN THE DIAGNOSIS OF BRAIN TUMOR. W.A. Knaus* and D.O. Davis* (Intr. by S.A. Schroeder), Washington, D.C. AFCR page $298 \mathrm{~A}$

5. VOLUNTARY AND MANDATORY PRESURGICAL SCREENING PROGRAMS: AN ANALYSIS OF THEIR IMPLICATIONS. E.G. McCarthy and A.S. Kamons, ${ }^{*}$ New York, New York.

AFCR page 299A

6. PATTERNS OF CARE AND OUTCOMES IN THE COMMON COLD. J.D. Bristow, ** M.R. Greenlick,* A.V. Hurtado,* and D. Azevedo, ${ }^{*}$ Portland, Oregon. AAP page $479 A$

7. A PROSPECTIVE STUDY OF CHEST PAIN: CLINICAL FINDINGS, DIAGNOSES, AND OUTCOMES IN 147 UNSELECTED PATIENTS. H.C. Sox,* C. Shapiro,* and C.H. Sox* (Intr. by D.D. Federman**), Stanford, California. AFCR page $301 \mathrm{~A}$
8. A PROTOCOL FOR THE EXCLUSION OF CURABLE HYPERTENSION. C.E. Grim, J.T. Higgins, ${ }^{*}$ and M.H. Weinberger, Indianapolis, Indiana.

AFCR page 297A

9. ROLE OF CHRONIC HYPERTENSION AND PLASMA RENIN AS INDEPENDENT RISK FACTORS IN CORONARY PATIENTS: LACK OF RELATION TO SEVERITY OF CORONARY DISEASE AND CARDIAC FUNCTION. M.J. Tonkon,* R.R. Miller, P. Ternahan,* R. O'Connor,* J.F. Kraus, ${ }^{*}$ N.O. Borhani,** and D.T. Mason,** Davis, California.

AFCR page $250 A$

10. ABNORMAL LYMPHOCYTE RESPONSES IN RESIDENTS OF A TOWN WITH A CLUSTER OF HODGKIN'S DISEASE. J. Plouffe,* J. Callen,* R. Schwartz,* J. Allen,* and J. Silva, Ann Arbor, Michigan.

AFCR page $249 A$

11. SEVERITY OF SYMPTOMS AND CO-MORBIDITY: CRUCIAL CLINICAL OMISSIONS IN CURRENT STAGING SYSTEMS FOR CANCER. A.R. Feinstein** and C.K. Wells, New Haven, Connecticut. AAP page $475 A$

12. COMPUTER-BASED CHART AUDIT TO DETECT OVERUTILIZATION OF LABORATORY TESTS. J. Eisenberg,* L. Garner,* S. Williams, * H. Smits,* and R. Viale* (Intr. by M. Goldberg**), Philadelphia, Pennsylvania.

AFCR page $296 \mathrm{~A}$

13. PRE-THERAPEUTIC CLINICAL MORBIDITY IN PROGNOSTIC STAGING FOR ACUTE LEUKEMIA. N.F. Boyd,* J.D. Clemens, ${ }^{*}$ and A.R. Feinstein,** New Haven, Connecticut, and Montreal, Quebec, Canada. ASCI page 422A

1976 Programs $\cdot$ ASCI-AFCR-AAP xix 


\section{Ramada Inn 1:30 P.M. \\ John L. McNay and Elliot S. Vesell, Presiding}

1. A NOVEL METHOD FOR DETERMINING BIOAVAILABILITY: APPLICATION TO CHENODEOXYCHOLIC ACID. G.P. van Berge Henegouwen,* A.F. Hofmann, and P.Y.S. Yu, ${ }^{*}$ Rochester, Minnesota. ASCI page 424A

2. IMPAIRED HYDROLYSIS OF COCAINE IN PLASMA FROM SUCCINYLCHOLINE SENSITIVE INDIVIDUALS. P. Jatlow, P.L. Barash,* C. Van Dyke, ${ }^{*}$ and R. Byck, ${ }^{*}$ New Haven, Connecticut. AFCR page $255 A$

3. REVERSAL OF MASSIVE DIGITOXIN TOXICITY WITH SPECIFIC Fab FRAGMENTS. H. Ochs* and T.W. Smith, Boston, Massachusetts.

ASCI page 424A

4. ANTIARRHYTHMIC EFFICACY OF N-ACETYLPROCAINAMIDE IN PATIENTS WITH PREMATURE VENTRICULAR CONTRACTIONS. W.-K. Lee, ${ }^{*}$ J.M. Strong, * R.F. Kehoe, ${ }^{*}$ J.S. Dutcher, ${ }^{*}$ and A.J. Atkinson, Jr., Chicago, Illinois.

AFCR page $256 \mathrm{~A}$

5. ENHANCED BIOAVAILABILITY OF ENCAPSULATED DIGOXIN SOLUTION GIVEN WITH MEALS. J. Lindenbaum** and G.I. Mallis,* New York, New York.

AFCR page $256 \mathrm{~A}$

6. PHARMACOKINETICS OF QUINIDINE IN PATIENTS WITH CARDIAC DISEASE. K.A. Conrad,* B. Molk,* and C.A. Chidsey, ${ }^{* *}$ Denver, Colorado.

AFCR page $252 A$
7. DIGITALIS-INDUCED ARRHYTHMIAS ASSOCIATED WITH NORMOKALEMIC POTASSIUM DEPLETION AND ALKALOSIS. D.C. Brater* and H.F. Morrelli * (Intr. by H.R. Bourne), San Francisco, California. AFCR page $252 A$

8. ANTAGONISM OF THE ANTIHYPERTENSIVE AND SYMPATHOPLEGIC EFFECTS OF GUANETHIDINE BY EPHEDRINE IN MAN. R.L. Woosley,* I. Walter, ${ }^{*}$ J.A. Oates, ${ }^{* *}$ and A.S. Nies, Nashville, Tennessee.

AFCR page $259 A$

9. AFFINITY OF PROPRANOLOL FOR THE BETA RECEPTOR IN MAN. D.G. Shand, M. FriskHolmberg,* J.W. Hollifield,* and D.G. McDevitt,* Nashville, Tennessee. ASCI page 424A

10. KALLIKREIN ACTIVITY IN HUMAN URINE: THE INFLUENCE OF RACE. J.J. Lilley, L. Hsu, * R. Frigon,* and R.A. Stone, San Diego, California. AFCR page $256 A$

11. CONFORMATIONAL REQUIREMENTS FOR DOPAMINE-INDUCED VASODILATION. P.H. Volkman,* J.D. Kohli, ${ }^{*}$ L.I. Goldberg,** T. Lee, ${ }^{*}$ and J.D. Cannon,* Chicago, Illinois, and Iowa City, Iowa. AAP page $475 A$

12. VARIABILITY OF HEPATIC MICROSOMAL RESPONSE TO LIVER DISEASE AND DIPHENYLHYDANTOIN. G.W. Hepner* and E.S. Vesell, Hershey, Pennsylvania. ASCI page $423 \mathrm{~A}$

13. PLASMA 1,25-DIHYDROXYVITAMIN D LEVELS IN PATIENTS ON ANTICONVULSANT DRUGS. W. Jubiz, M.R. Haussler, K.G. Tolman, and T.A. McCain,* Salt Lake City, Utah, and Tucson, Arizona.
Teakwood Room, LaFayette 1:30.R.M.

Andrew H. Kang and John J. Voorhees, Presiding

1. INITIATION OF MAMMALIAN EPIDERMAL PROTEIN SYNTHESIS. I.M. Freedberg and M.E. Gilmartin,* Boston, Massachusetts. ASCI page $425 \mathrm{~A}$

2. ISOLATION AND CHARACTERIZATION OF TYPE I AND TYPE III COLLAGEN. J.M. Seyer,* D.A. Swann,* D.M. Brickley,* and M.J. Glimcher* (Intr. by A.E. Postlethwaite), Memphis, Tennessee, and Boston, Massachusetts. AFCR page 267A

3. POLYPEPTIDE COMPOSITION OF THE FIBROUS PROTEINS OF PIG AND CALF EPIDERMIS. L.D. Lee* and H.P. Baden, ${ }^{* *}$ Boston, Massachusetts. AFCR page $265 \mathrm{~A}$
4. REGULATION OF EPIDERMAL TRANSGLUTAMINASE. H. Ogawa* and L.A. Goldsmith, Durham, North Carolina. AFCR page $266 \mathrm{~A}$

5. CELL CULTURE DENSITY AS A MODULATOR OF COLLAGENASE ACTIVITY IN NORMAL HUMAN SKIN FIBROBLAST CULTURES. E.A. Bauer, J.J. Jeffrey,* and A.Z. Eisen, St. Louis, Missouri. AFCR page $261 A$

6. KERATINOCYTES CONTAIN ACTIN. J. McGuire, E. Lazarides, ${ }^{*}$ and A. DiPasquale, ${ }^{*}$ New Haven, Connecticut, and Boulder, Colorado.

ASCI page 425A

7. A RETICULOEPITHELIAL SYSTEM: CUTANEOUS TRAP FOR ANTIGENS. W.B. Shelley** and L. Juhlin*, Philadelphia, Pennsylvania.

AAP page $476 A$ 
8. ROLE OF DELAYED HYPERSENSITIVITY IN CLEARANCE OF ORGANISMS FROM EXPERIMENTAL CUTANEOUS CANDIDIASIS. P.G. Sohnle* and C.H. Kirkpatrick, Bethesda, Maryland. ASCI page 425A

9. SALINE SOLUBLE ANTIGENS COMMON TO EPIDERMIS, ESOPHAGUS, SALIVA AND URINE. L.A. Diaz, ${ }^{*}$ N.J. Calvanico, ${ }^{*}$ and R.E. Jordon* (Intr. by S.F. Phillips), Rochester, Minnesota.

ASCI page 425A

10. Ro 20-1724 ELEVATES EPIDERMAL CYCLIC ADENOSINE MONOPHOSPHATE LEVELS IN VITRO AND IMPROVES PSORIASIS IN VIVO. M. Stawiski,* L. Rusin,* M.A. Schork, ${ }^{*}$ T. Burns, ${ }^{*}$ E. Duell, and J. Voorhees, Ann Arbor, Michigan.

AFCR page $267 A$
11. COLD URTICARIA: THE APPEARANCE IN THE CIRCULATION OF A NEUTROPHIL CHEMOTACTIC PRINCIPLE DURING COLD CHALLENGE. S.I. Wasserman, ${ }^{*}$ N.A. Soter, D.M. Center, ${ }^{*}$ and K.F. Austen, ${ }^{* *}$ Boston, Massachusetts.

AFCR page $268 \mathrm{~A}$

12. DRUG PHOTOSENSITIZATION IN MAN FOLLOWING PARENTERAL EXPOSURE TO HEMATOPORPHYRIN. G. Zalar,* M. Poh-Fitpatrick, ${ }^{*}$ D. Krohn,* and R. Jacobs* (Intr. by L.C. Harber**), New York, New York.

ASCI page 425A

13. INHIBITION OF LYSYL OXIDASE BY HOMOCYSTEINE: A PROPOSED CONNECTIVE TISSUE DEFECT IN HOMOCYSTINURIA. K.A. Lindberg, * A. Hassett,* and S.R. Pinnell, Durham, North Carolina.

AFCR page $265 A$
Pennsylvania Room III, Haddon Hall 1:30 P.M.

C. Wayne Bardin and Gerald S. Levey, Presiding

1. A NEW DIRECT METHOD FOR DETECTION AND CHARACTERIZATION OF CELL SURFACE RECEPTORS FOR INSULIN USING SPECIFIC ${ }^{125}$ IRECEPTOR AUTOANTIBODIES. D.B. Jarrett* and J. Roth (Intr. by P. Gorden), Bethesda, Maryland. ASCI page $427 A$

2. 'MOLECULAR MECHANISMS OF CATECHOLAMINE-INDUCED DESENSITIZATION AND RESENSITIZATION OF BETA-ADRENERGIC RECEPTORS. R.J. Lefkowitz and C. Mukherjee, * Durham, North Carolina. ASCI page $428 \mathrm{~A}$

3. DIRECT MEASUREMENT OF L-THYROXINE AND L-TRIIODOTHYRONINE AT THYROID HORMONE RECEPTOR SITES IN RAT LIVER NUCLEI. M.I. Surks and J.H. Oppenheimer,** Bronx, New York.

ASCI page $430 \mathrm{~A}$

4. DEMONSTRATION OF SEQUENTIAL MONODEIODINATION AS THE MAJOR PATHWAY OF IODOTHYRONINE METABOLISM. M. Rudolph,* T. Sakurada,* A. Vagenakis, ${ }^{*}$ S. Fang,* L. Braverman, ${ }^{* *}$ and S. Ingbar, ${ }^{* *}$ Denver, Colorado; Boston and Worcester, Massachusetts. ASCI page 429A

5. INDUCTION BY THYROTROPIN OF A PROTEIN INHIBITOR OF THE CYCLIC ADENOSINE MONOPHOSPHATE RESPONSE TO SERUM THYROTROPIN IN CULTURED THYROID CELLS. B. Rapoport and R.J. Adams, * San Francisco, California.

AFCR page $276 \mathrm{~A}$

6. MITOCHONDRIAL THYROID HORMONE BINDING AND ACTIVATION. J.H. Lazarus, * P.O. Milch,* and K. Sterling,** Bronx and New York, New York. ASCI page $428 A$
7. SELECTIVE LOSS OF VASOPRESSIN SECRETION AND THIRST DUE TO OSMORECEPTOR DYSFUNCTION. R. Shelton* and G. Robertson, Indianapolis, Indiana. AFCR page 278 A

8. SARALASIN ACETATE INFUSION IN THE RECOGNITION OF RENOVASCULAR HYPERTENSION. H.M. Wilson,* P.E. Slaton, Jr.,** J.P. Wilson,* G.W. Liddle, ** J.H. Foster, ${ }^{*}$ and J.W. Hollifield, * Nashville, Tennessee. $\quad$ AFCR page $280 \mathrm{~A}$

9. EFFECT OF SODIUM RESTRICTION AND INDOMETHACIN ON THE RENIN-ANGIOTENSIN AND PROSTAGLANDIN SYSTEMS IN MAN. P. Speckart,* P. Zia, ${ }^{*}$ R. Zipser, ${ }^{*}$ and R. Horton, ${ }^{* *}$ Los Angeles, California. AFCR page $278 A$

10. MODULATING ACTIONS OF EXTRACELLULAR SODIUM CONCENTRATION ON ALDOSTERONE PRODUCTION BY ZONA GLOMERULOSA CELLS. J. Douglas, * S. Saltman, * P. Fredlund,* T. Kondo,* and K. Catt, Bethesda, Maryland.

ASCI page $427 A$

11. MECHANISM OF EFFECT OF GLUCOCORTICOID DEFICIENCY ON RENAL WATER EXCRETION IN THE CONSCIOUS DOG. J. Boykin,* A. McCool,* K. McDonald, G. Robertson; and R. Schrier, Denver, Colorado, and Indianapolis, Indiana. AFCR page 269A

12. A RECIPROCAL RELATIONSHIP BETWEEN THYROID-RELEASING HORMONE AND DOPAMINE IN REGULATING THE RELEASE OF PITUITARY HORMONES. P.B. May,* G.N. Burrow,* S.W. Spaulding,* and R.K. Donabedian* (Intr. by G. Cohn), New Haven, Connecticut. ASCI page 428A

13. AROMATIZATION OF ANDROSTENEDIONE BY CULTURED HUMAN FIBROBLASTS. H.-U. Schweikert,* L. Milewich,* and J.D. Wilson, Dallas, Texas. ASCI page 430A

1976 Programs · ASCI-AFCR-AAP xxi 
Vernon Room, Haddon Hall

1:30 P.M.

Young S. Kim and Daniel V. Kimberg, Presiding

1. CHLORPROMAZINE METABOLITES-INHIBITORS OF $\mathrm{Na}^{+}, \mathrm{K}^{+}$ADENOSINE TRIPHOSPHATASE IN LIVER PLASMA MEMBRANES ENRICHED IN BILE CANALICULI. J.L. Boyer and M. Root,* Chicago, Illinois. AFCR page 281A

2. CHARACTERIZATION OF BILE ACID BINDING TO BRUSH BORDER MEMBRANES. F.A. Wilson and L.L. Treanor, ${ }^{*}$ Nashville, Tennessee. AFCR page $293 \mathrm{~A}$

3. RELATIONSHIP OF HEPATIC BILIRUBIN EXCRETION TO FASTING AND FEEDING IN MAN. D.T. Lyon,* J.R. Ashkin, * C.I. Wagner, * B.W. Trotman, and R.D. Soloway, Philadelphia, Pennsylvania. AFCR page $288 \mathrm{~A}$

4. DEFECTIVE T-LYMPHOCYTE-SPECIFIC CYTOTOXICITY IN PRIMARY BILIARY CIRRHOSIS BUT NOT IN CHRONIC HEPATITIS. J.M. Vierling,* D.L. Nelson,* W. Strober, B.M. Bundy,* and E.A. Jones, ${ }^{*}$ Bethesda, Maryland. AFCR page $293 A$

5. LIVER COLLAGEN SYNTHESIS IN MURINE SCHISTOSOMIASIS. M.A. Dunn, M. Rojkind, ${ }^{*}$ and K.S. Warren, ** Bronx, New York, and Cleveland, Ohio.

AFCR page $283 \mathrm{~A}$

6. THE SIZE OF GLYCINE OLIGOPEPTIDE WHICH LIMITS INTACT ABSORPTION IN HUMAN JEJUNUM. S. Adibi and E. Morse,* Pittsburgh, Pennsylvania. ASCI page $431 \mathrm{~A}$

7. IMMUNOFLUORESCENT LOCALIZATION OF APOPROTEIN B IN INTESTINAL EPITHELIAL CELLS. R.M. Glickman, A. Kilgore, ${ }^{*}$ and J. Khorana,* Boston, Massachusetts. AFCR page $285 \mathrm{~A}$
8. EFFECT OF VASOACTIVE INTESTINAL PEPTIDE ON COLONIC TRANSPORT AND ADENYLATE CYCLASE ACTIVITY: BLOCKADE BY LACTAMIMIDE. D.B. Waldman,* J.D. Gardner,** A.M. Zfass,* and G.M. Makhlouf, ${ }^{* *}$ Richmond, Virginia, and Bethesda, Maryland. AFCR page 293A

9. STUDIES OF THE ROLE OF FATTY ACID BINDING PROTEIN IN THE UTILIZATION OF FREE FATTY ACID BY ISOLATED HEPATOCYTES. D.A. Burnett* and R.K. Ockner, San Francisco, California. ASCI page $432 \mathrm{~A}$

10. MODULATION OF HORMONE RESPONSE IN PANCREATIC ACINAR CELLS: BIOCHEMICAL REGULATION OF INITIAL STEP IN ACTION OF SECRETIN AND VASOACTIVE INTESTINAL PEPTIDE. E. Olinger* and J. Gardner, Bethesda, Maryland. AFCR page 289A

11. HEARTBURN OF PREGNANCY-A HORMONAL DISORDER. R.S. Fisher, G.S. Roberts, ${ }^{*}$ C.J. Grabowski,* and S. Cohen, Philadelphia, Pennsylvania. AFCR page $284 \mathrm{~A}$

12. PREFERENTIAL TRANSPORT OF HORSERADISH PEROXIDASE BY M CELLS OVER PEYER'S PATCH LYMPHOID FOLLICLES. R.L. Owen* (Intr. by A.L. Jones), San Francisco, California. ASCI page 434A

13. PHLORIZIN BINDING PROPERTIES OF BRUSH BORDER MEMBRANES OF RAT INTESTINE. J.E. Franklin,* G. Luk,* and K.J. Isselbacher** (Intr. by L.J. Kagen), New York, New York, and Boston, Massachusetts. AFCR page $284 A$

\section{Garden Room, Haddon Hall} 1:30 P.M.

Walter E. Nance and William S. Sly, Presiding

1. EVIDENCE FROM TWINS FOR A GENETIC INFLUENCE ON THE RENIN-ALDOSTERONE SYSTEM IN NORMAL MAN. C.E. Grim, W.E. Nance,** J.C. Christian, R.J. Rose,* D.H. Henry, and M.H. Weinberger, Indianapolis, Indiana.

AFCR page $294 A$

2. HUMAN PHOSPHORIBOSYLPYROPHOSPHATE SYNTHETASE: RELATION OF ACTIVITY TO QUATERNARY STRUCTURE. L.J. Meyer and M.A. Becker, San Diego, California.

AFCR page 295A
3. ADENINE PHOSPHORIBOSYLTRANSFERASE DEFICIENCY: EVIDENCE FOR GENETIC HETEROGENEITY. I.H. Fox, S. Lacroix, ${ }^{*}$ and $M$. Moore,* Toronto, Ontario, Canada.

AFCR page $294 A$

4. INDUCTION OF FETAL HEMOGLOBIN SYNTHESIS IN VITRO. T. Papayannopoulou,* M. Brice,* and G. Stamatoyannopoulos, Seattle, Washington. ASCI page 435A

5. DETECTION OF HETEROZYGOTES FOR TYROSINASE-NEGATIVE OCULOCUTANEOUS ALBINISM BY HAIRBULB TYROSINASE ASSAY. R.A. King and C.J. Witkop, Jr., ${ }^{*}$ Minneapolis, Minnesota. AFCR page 294A 
6. ENHANCED URIDINE DIPHOSPHATE GALACTOSE: GLYCOPROTEIN GALACTOSYLTRANSFERASE IN CULTIVATED SKIN FIBROBLASTS OF PATIENTS WITH CYSTIC FIBROSIS. G.J.S. Rao,* G. Spells, ${ }^{*}$ and H.L. Nadler, Chicago, Illinois. ASCI page 435A

7. PROTOPORPHYRIA: EXPRESSION OF THE BIOCHEMICAL DEFECT IN CULTURED SKIN FIBROBLASTS. J.R. Bloomer and M.J. Mahoney,* New Haven, Connecticut.

AFCR page $294 A$

8. DEMONSTRATION OF IN VITRO RESPONSIVENESS TO BIOTIN IN FIBROBLASTS OF A PATIENT WITH 3-METHYLCROTONYLGLYCINURIA AND PROPIONIC ACIDEMIA. W. Weyler,* L. Sweetman,* and W.L. Nyhan,** San Diego and La Jolla, California.

AFCR page $295 A$

9. APPLICATION OF MOLECULAR HYBRIDIZATION TO PRENATAL DIAGNOSIS OF $\alpha$ THALASSEMIA. Y.W. Kan, M.S. Golbus, ${ }^{*}$ and A.M. Dozy,* San Francisco, California.

ASCI page 435A
10. PRENATAL DIAGNOSIS OF HEMOGLOBINOPATHIES: EXPERIENCE IN 17 CASES. B.P. Alter,* A.S. Sherman,* J.C. Hobbins, ${ }^{*}$ M.J. Mahoney,* C.B. Modell,* D. Fairweather, ${ }^{*}$ F.D. Frigoletto, ${ }^{*}$ and D.G. Nathan, Boston, Massachusetts; New Haven, Connecticut; and London, England.

AFCR page $293 A$

11. PRENATAL DIAGNOSIS OF PROPIONIC ACIDEMIA BY ORGANIC ACID ANALYSIS. L. Sweetman,* W. Weyler,* T. Shafai,* P.E. Young,* and W.L. Nyhan,** Riverside, San Diego, and La Jolla, California. AFCR page $295 A$

12. TRICHOPOLIODYSTROPHY: A GENETIC DEFECT IN SELECTIVE COPPER BINDING AND STORAGE AS WELL AS TRANSPORT. R.I. Henkin and W.D. Grover, ${ }^{*}$ Washington, D.C., and Philadelphia, Pennsylvania. ASCI page 435A

13. MONOCYTE-DERIVED MACROPHAGES: A NEW IN VITRO SYSTEM FOR STUDYING THE DIAGNOSIS AND THERAPY OF HEREDITARY LYSOSOMAL STORAGE DISEASES. S. Yatziv,* L.B. Epstein,* and C.J. Epstein, San Francisco, California.
Windsor Room, Haddon Hall 1:30 P.M.

H. Franklin Bunn and Harry S. Jacob, Presiding

1. THE EFFECT OF INDUCED FEVER ON SERUM IRON AND FERRITIN CONCENTRATION IN MAN. R.J. Elin, S.M. Wolff, ${ }^{* *}$ and C.A. Finch,** Bethesda, Maryland, and Seattle, Washington.

AFCR page 306A

2. EFFECT OF GALACTOSE OXIDASE ON ERYTHROCYTE SURVIVAL. J.R. Durocher and M.E. Conrad,** Philadelphia, Pennsylvania, and Birmingham, Alabama.

AFCR page $306 A$

3. KINETICS OF OXYGEN UPTAKE BY SICKLE RED CELLS. M.J. Messer, J.A. Hahn, ${ }^{*}$ and T.B. Bradley,** San Francisco, California.

AFCR page $315 \mathrm{~A}$

4. CHANGES IN ARRANGEMENT OF RED CELL MEMBRANE PROTEINS DURING ADENOSINE TRIPHOSPHATE DEPLETION. J. Palek, S.C. Liu,* A. Liu,* N. Fortier,* L.M. Snyder, and G. Fairbanks,* Worcester and Shrewsbury, Massachusetts. AFCR page $316 A$
5. PLATELET TRANSFUSION REFRACTORINESS AND DONOR SELECTION. K.K. Wu, J.C. Hoak,** J.S. Thompson, ${ }^{* *}$ and J.A. Koepke, ${ }^{* *}$ lowa City, Iowa. AFCR page $323 \mathrm{~A}$

6. ESSENTIAL PROTEINS FOR CONTACT ACTIVATION OF HAGEMAN FACTOR PATHWAYS. J.H. Griffin,* G. Beretta,* A. Kleiss,* S.D. Revak,* and C.G. Cochrane, La Jolla, California.

ASCI page $439 \mathrm{~A}$

7. MULTIPLE MOLECULAR FORMS OF FACTOR VIII-RELATED ANTIGEN IN NORMAL PLASMA: RELATIONSHIP TO MOLECULAR ABNORMALITIES IN VON WILLEBRAND'S DISEASE. T.S. Zimmerman,* C.F. Abildgaard,* and T.S. Edgington (Intr. by N.R. Cooper), La Jolla and Sacramento, California. ASCI page 444A

8. PROSTAGLANDIN $D_{2}$, A FEEDBACK INHIBITOR OF PLATELET AGGREGATION? O. Oelz,* $\mathrm{R}$. Oelz,* B.J. Sweetman,* and J.A. Oates, ** Nashville, Tennessee. AFCR page $316 \mathrm{~A}$

1976 Programs $\cdot$ ASCI-AFCR-AAP xxiii 
9. MEMBRANE MICROVISCOSITY AND PLATELET FUNCTION. S.J. Shattil, J. Turnbull,* and R.A. Cooper, Philadelphia, Pennsylvania.

AFCR page 319A

10. THE EFFECT OF CONTRACTILE PROTEIN ANTISERA ON POLYMORPHONUCLEAR LEUKOCYTE FUNCTION. L.A. Boxer,* A. Floyd,* S. Richardson,* and R.L. Baehner (Intr. by W. Daly), Indianapolis, Indiana.

ASCI page 437A

11. EFFECTS OF GRADED MYELOSUPPRESSION ON STEM CELL AND GRANULOCYTE GROWTH IN AN IN-VIVO CULTURE SYSTEM. W.S. Tyler, P.
Quesenberry, M. Chovaniec,* M. Ryan,* and D. Howard,* Boston, Massachusetts.

AFCR page $322 \mathrm{~A}$

12. MOLECULAR BASIS FOR STIMULATION OF POLYMORPHONUCLEAR LEUKOCYTES BY IMMUNOGLOBULINS. I.M. Goldstein,* H. Schieren,* and G. Weissmann, New York, New York.

ASCI page 439A

13. ACTIVATION OF GRANULOCYTE $\mathrm{O}_{2}$ : AND $\mathrm{H}_{2} \mathrm{O}_{2}$ PRODUCTION BY THE IONOPHORE A23187. R.K. Root and J. Metcalf,* New Haven, Connecticut.

\section{Immunology and Connective Tissue}

\section{Rutland Room, Haddon Hall 1:30 P.M.}

Thomas A. Waldmann and Ralph C. Williams, Jr.. Presiding

1. ANTINUCLEAR ANTIBODY WITH DISTINCT SPECIFICITY IN POLYMYOSITIS. J.F. Wolfe* and G.C. Sharp, ${ }^{* *}$ Columbia, Missouri.

AFCR page 338A

2. EFFECTIVE PROPHYLAXIS OF HEREDITARY ANGIOEDEMA BY AN IMPEDED ANDROGEN, DANAZOL. J.A. Gelfand,* R.J. Sherins,* D.W. Alling, ${ }^{*}$ and M.M. Frank, Bethesda, Maryland. ASCI page 446A

3. ALPHA-FETOPROTEIN IN CANCER-PRONE FAMILIES. R.H. Keller, ${ }^{*}$ H. Guirgis,* H. Lynch,* and T.B. Tomasi, Jr., ${ }^{* *}$ Rochester, Minnesota, and Omaha, Nebraska. AFCR page $331 A$

4. SUPPRESSION OF POLYMORPHONUCLEAR LEUKOCYTE CHEMOTAXIS BY SERA FROM PATIENTS WITH IMMUNOGLOBULIN A MYELOMA. D. Van Epps and R.C. Williams, Jr., ${ }^{* *}$ Albuquerque, New Mexico. AFCR page $338 A$

5. IMPAIRED IMMUNE SURVEILLANCE IN CHRONIC LYMPHOCYTIC LEUKEMIA AND SYSTEMIC LUPUS ERYTHEMATOSUS. M.M. Kuntz,* J.B. Innes, ${ }^{*}$ and M.E. Weksler, New York, New York. ASCI page $448 \mathrm{~A}$

6. PRODUCTION OF EOSINOPHILOTACTIC PEPTIDES BY BRONCHOGENIC CARCINOMA IN SITU AND IN VITRO. E.J. Goetzl, R.H. Rubin,* J. McDonough,* A.H. Tashjian, Jr., ${ }^{*}$ and K.F. Austen, ${ }^{* *}$ Boston, Massachusetts. $\quad$ ASCI page $447 A$

7. NON-H-COMPLEX-LINKED B-LYMPHOCYTE ANTIGENS IN GLUTEN-SENSITIVE ENTEROPATHY AND DERMATITIS HERPETIFORMIS. S.I. Katz,* D.L. Mann, D.L. Nelson,* L.D. Abelson,* and W. Strober, Bethesda, Maryland.

ASCI page 447A
8. T DEPENDENT IMMUNOSUPPRESSION. J.D. Stobo,* S. Paul,* R. Van Scoy,* and P. Hermans* (Intr. by F.C. McDuffie), Rochester, Minnesota.

AFCR page $337 A$

9. A HUMAN B CELL AND MONOCYTE ALLOANTIGEN SYSTEM SPATIALLY RELATED TO MEMBRANE Fc RECEPTORS. C.B. Carpenter, A.J.F. d'Apice, ${ }^{*}$ and J.-P. Soulillou, ${ }^{*}$ Boston, Massachusetts. ASCI page 445A

10. SAA-THE SERUM PRECURSOR OF THE AA PROTEIN. C.J. Rosenthal, E.C. Franklin, ${ }^{* *}$ B. Frangione, ${ }^{* *}$ and J. Greenspan, New York, New York. ASCI page 449A

11. RECONSTITUTION OF A CHILD WITH SEVERE COMBINED IMMUNODEFICIENCY AND TRANSPLANT-INDUCED APLASIA WITH MARROW FROM AN UNRELATED, HLA AND ABO NONIDENTICAL, MIXED LYMPHOCYTE CULTURE COMPATIBLE DONOR. R.J. O'Reilly, B. Dupont, S. Pahwa, E. Grimes, R. Pahwa, S. Schwartz, E.M. Smithwick, A. Svejgaard, C. Jersild, J. Hansen, and R.A. Good, ${ }^{* *}$ New York, New York.

AAP page $482 A$

12. PASSIVE TRANSFER OF ONE PARAMETER OF CELL-MEDIATED IMMUNITY WITH DIALYZABLE TRANSFER FACTOR. J.M. Goust, E. Eylar," T.A. Mahvi,* M. Arala-Chaves,* and H.H. Fudenberg, ${ }^{* *}$ Charleston, South Carolina.

AFCR page $328 \mathrm{~A}$

13. IN VITRO ANTIBODY SYNTHESIS AND SUPPRESSION IN HUMORAL IMMUNODEFICIENCY STATES. H.M. Dosch* and E.W. Gelfand* (Intr. by R.P. Orange), Toronto, Ontario, Canada.

$A A P$ page $481 A$ 
Viking Room, Haddon Hall

1:30 P.M.

Ward E. Bullock and William B. Greenough, Presiding

1. THE NEONATAL FORMATION OF STREPTOCOCCAL BINDING SITES IN ORAL EPITHELIAL CELLS IN MAN. E.H. Beachey,* I. Ofek, ${ }^{*}$ and F. Ey al* (Intr. by G.H. Stollerman**), Memphis, Tennessee.

ASCI page 451A

2. THE NUDE MOUSE: A NEW EXPERIMENTAL MODEL FOR PNEUMOCYSTIS CARINII INFECTION. P.D. Walzer, V. Schnelle,* D. Armstrong,** and P.P. Rosen, ${ }^{*}$ New York, New York.

AFCR page 354A

3. GONOCOCCAL ENDOCARDITIS AND HEPATITIS IN THE RABBIT. R.L. Kaspar* and D.J. Drutz, San Antonio, Texas. AFCR page $346 A$

4. EVIDENCE FOR A SUBCELLULAR FACTOR IN GONOCOCCI TOXIC FOR HUMAN GENITAL MUCOSAL CELLS. Z.A. McGee, A.P. Johnson,* and D. Taylor-Robinson,* Nashville, Tennessee, and Harrow, England. AFCR page $349 A$

5. ANTIGENIC HETEROGENEITY AND ATTACHMENT ROLE OF GONOCOCCAL PILI. T.M. Buchanan,* W.A. Pearce,* G.K. Schoolnik, ${ }^{*}$ and K.K. Holmes, Seattle, Washington. ASCI page $451 A$

6. STIMULATION OF NEUTROPHIL METABOLISM BY ADHERENT AND INGESTED GONOCOCCI. P. Densen* and G.L. Mandell, Charlottesville, Virginia. AFCR page $342 A$
7. PATHOGENIC POTENTIAL AND ANTIBODY RESPONSE TO ENCAPSULATED BACTEROIDES FRAGILIS. D.L. Kasper, A.B. Onderdonk, ${ }^{*}$ and J.G. Bartlett, Boston, Massachusetts.

AFCR page $346 A$

8. SEROLOGICAL EVIDENCE FOR THE IN VIVO PRODUCTION OF LETHAL EXOTOXIN IN PATIENTS WITH PSEUDOMONAS INFECTIONS. $M$. Pollack, N.S. Taylor, ${ }^{*}$ and L.T. Callahan, ${ }^{*}$ Bethesda, Maryland. AFCR page $351 \mathrm{~A}$

9. INITIATION OF GRANULOCYTE $\mathrm{O}_{2}$ : AND $\mathrm{H}_{2} \mathrm{O}_{2}$ FORMATION BY STIMULATION OF MEMBRANE PHAGOCYTIC RECEPTORS. R.K. Root and J. Metcalf,* New Haven, Connecticut. AFCR page $352 A$

10. RADIOIMMUNOASSAY FOR SCHISTOSOMIASIS USING PURIFIED EGG ANTIGEN. R.P. Pelley* and K.S. Warren, ** Cleveland. Ohio.

AFCR page $351 A$

11. MEMBRANE RECEPTOR FOR SHIGELLA TOXIN: ROLE OF N-ACETYL GLUCOSAMINE. G.T. Keusch and M. Jacewicz,* New York, New York.

AFCR page $347 A$

12. EFFECTS OF ENDOTOXIN (LPS) ON BLOOD COAGULATION IN HUMANS. H.R. Gralnick, R.J. Elin, E. Abrams, ${ }^{*}$ H. Givelber, ${ }^{*}$ and S.M. Wolff, ${ }^{* *}$ Bethesda, Maryland. AFCR page $344 \mathrm{~A}$

\section{Pennsylvania Room I, Haddon Hall 1:30 P.M. \\ Ralph S. Goldsmith and Daniel Porte, Presiding}

1. HYPORENINEMIC HYPOALDOSTERONISM IN DIABETES MELLITUS. G. Perez, L. Lespier, ${ }^{*}$ J. Jacobi, ${ }^{*}$ J. Oster, F. Katz, ${ }^{* *}$ C. Vaamonde, ${ }^{* *}$ and L. Fishman,** Miami, Florida, and Denver, Colorado. AFCR page $367 A$

2. MUSCLE CAPILLARY BASEMENT MEMBRANE MEASUREMENTS IN PREDIABETIC, DIABETIC, AND NORMAL PIMA INDIANS AND NORMAL CAUCASIANS. S.L. Aronoff,* P.H. Bennett,* J.R. Williamson,* M.D. Siperstein,** M.E. Plumer, ${ }^{*}$ and M. Miller,** Phoenix, Arizona. $\quad$ ASCI page 455A
3. BINDING OF INSULIN TO ISOLATED NUCLEI: EVIDENCE FOR AN INTRACELLULAR SITE OF INSULIN ACTION. I.D. Goldfine* and G.J. Smith* (Intr. by M.D. Siperstein), San Francisco, California. ASCI page $457 \mathrm{~A}$

4. BIOCHEMISTRY AND PHYSIOLOGY OF A HUMAN SERUM NONSUPPRESSIBLE INSULINLIKE PROTEIN. P.L. Poffenbarger,* A. Medina,* M. Balch,* and S. Lee* (Intr. by W.P. Deiss, Jr.), Galveston, Texas.

ASCI page $460 A$ 
5. GASTRIC INHIBITORY POLYPEPTIDE RELEASE AFTER ORAL GLUCOSE AND QUANTIFICATION OF ITS NORMAL ROLE IN INSULIN SECRETION. D.K. Andersen,* J.C. Brown,* J.D. Tobin,* and R. Andres, ** Baltimore, Maryland, and Vancouver, British Columbia, Canada.

ASCI page $455 \mathrm{~A}$

6. SELECTIVE FAILURE OF PROLONGED INFUSION OF INSULIN TO NORMALIZE GLUCAGON RESPONSES TO GLUCOSE IN HUMAN DIABETES MELLITUS: EVIDENCE FOR A DEFECTIVE $\alpha$-CELL GLUCORECEPTOR. J.E. Gerich, M. Lorenzi, E. Tsalikian, N. Bohanon, V. Schneider, J. Karam, P.H. Forsham, and S.B. Lewis, San Francisco and Oakland, California.

AFCR page $361 \mathrm{~A}$

7. GLUCOSE AND 3-O-METHYLGLUCOSE PROTECTION AGAINST ALLOXAN INHIBITION OF GLUCAGON SECRETION. A.S. Pagliara, S.N. Stillings,* A. Williams, * W. Zawalich, ${ }^{*}$ and F.M. Matschinsky,* St. Louis, Missouri. ASCI page 459A

8. COMPLETE BILIARY DIVERSION AND ORAL BILE ACID THERAPY IN HOMOZYGOUS FAMILIAL HYPERCHOLESTEROLEMIA. R.J. Deckelbaum,* S.E. Hedberg,* S.M. Grundy, D.M. Small, and R.S. Lees, Boston, Massachusetts, and San Diego, California.

ASCI page $456 \mathrm{~A}$
9. METABOLISM OF HUMAN LIPOPROTEINS, HIGH DENSITY AND LOW DENSITY, BY FIBROBLASTS OF NORMAL AND OF HOMOZYGOUS FAMILIAL HYPERCHOLESTEROLEMIC SUBJECTS. N.E. Miller, ${ }^{*}$ D.B. Weinstein, ${ }^{*}$ and D. Steinberg, ${ }^{* *}$ San Diego and La Jolla, California.

ASCI page $459 \mathrm{~A}$

10. 25-HYDROXYVITAMIN D TRANSPORT IN HUMAN PLASMA: ISOLATION AND PARTIAL CHARACTERIZATION OF CALCIFIDIOL-BINDING PROTEIN. J.G. Haddad and J. Walgate, ${ }^{*}$ St. Louis, Missouri. ASCI page 458A

11. EFFECTS OF 25 HYDROXYVITAMIN $D_{3}$ IN THE INTACT AND ACUTELY THYROPARATHYROIDECTOMIZED DOG. R. Peraino,* E. Ghaffary, ${ }^{*}$ D. Rouse,* and W.N. Suki, Houston, Texas.

ASCI page $460 \mathrm{~A}$

12. MODULATION OF CULTURED BONE CELL MORPHOLOGY BY PARATHYROID HORMONE: POSSIBLE INTERPLAY BETWEEN MICROTUBULES AND MICROFILAMENTS. S.S. Miller, A.M. Wolf, and C.D. Arnaud,** Rochester, Minnesota. ASCI page $459 \mathrm{~A}$

13. A STUDY OF THE PATHOGENESIS OF IDIOPATHIC HYPERCALCIURIA. F. Shen, * D. Baylink, R. Nielsen,* D. Sherrard,* and M. Haussler,* Seattle, Washington, and Tucson, Arizona. ASCI page $460 A$

\section{Metabolism Poster Session}

\section{Exhibit Hall \\ 3:00-5:00 P.M.}

1. METABOLIC ROLE OF KETONES IN STARVATION AND DIABETES: REGULATOR OF BRANCHED-CHAIN AMINO ACID OXIDATION. H. Paul* and S. Adibi,** Pittsburgh, Pennsylvania. page $367 \mathrm{~A}$

2. IMPAIRED INTESTINAL CALCIUM ABSORPTION IN POST-MENOPAUSAL OSTEOPOROSIS: POSSIBLE ROLE OF VITAMIN D METABOLITES AND PARATHYROID HORMONE. C. Gallagher,* L. Riggs, ${ }^{* *}$ J. Eisman,* S. Arnaud,** and H. DeLuca, ${ }^{*}$ Rochester, Minnesota, and Madison, Wisconsin. page $360 \mathrm{~A}$

3. SELECTIVE $\beta_{1}$ RECEPTOR MEDIATION OF PARATHYROID HORMONE SECRETION. S.C. Kukreja, P. Banerjee,* G. Ayala,* E.N. Bowser,* G.K. Hargis, ${ }^{*}$ W.J. Henderson,* and G.A. Williams, ** Chicago, Illinois.

page $363 \mathrm{~A}$

4. PROLINE METABOLISM IN CARTILAGE: AN IMPORTANT ROLE FOR PROLINE BIOSYNTHESIS. R.J. Smith,* S.J. Downing,* and J.M. Phang, Bethesda, Maryland.

page $371 \mathrm{~A}$
5. DEVELOPMENTAL REGULATION OF PROLINE METABOLISM. E.M. Kowaloff,* A.S. Granger, ${ }^{*}$ and J.M. Phang, Bethesda, Maryland. page $363 \mathrm{~A}$

6. INCREASED URINE NON-DIALYZABLE HYDROXYPROLINE IN SODIUM FLUORIDE TREATED PATIENTS WITH OSTEOPOROSIS. J. Rosenquist,* E. Manzke,* D. Baylink, J. Wergedal,* R. Rawley,* and G. Vose, ${ }^{*}$ Seattle, Washington, and Denton, Texas. page $369 \mathrm{~A}$

7. CARBOHYDRATE TRANSPORT, GLUCOSE METABOLISM, AND THEIR STIMULATION BY INSULIN IN ISOLATED RAT ADIPOSE CELLS: EFFECTS OF CELL SIZE. J.E. Foley,* S.W. Cushman, and L.B. Salans, Hanover, New Hampshire.

page $360 A$

8. EFFECTS OF DIET AND DRUGS ON PLASMA CHOLESTANOL AND BILIARY BILE ACID COMPOSITION IN CEREBROTENDINOUS XANTHOMATOSIS. A.K. Bhattacharyya and W.E. Connor,** New Orleans, Louisiana, and Portland, Oregon.

page $356 \mathrm{~A}$ 
9. PLASMA PROSTAGLANDINS IN HYPERCALCEMIC PATIENTS WITH NEOPLASTIC DISEASE. L. Demers,* J. Allegra, H. Harvey,* A. Lipton, J. Luderer,* D. White,* M. Gillin, ${ }^{*}$ and D. Brenner,* Hershey, Pennsylvania.

page $359 \mathrm{~A}$
10. UPTAKE AND METABOLISM OF L-3,4-DIHYDROXYPHENYLALANINE IN ISOLATED INTESTINAL CELLS: FORMATION AND RELEASE OF DOPAMINE GLUCURONIDE. J.S. Stoff, M. Baranano,* M.B. Berardino,* and L. Landsberg, Boston, Massachusetts.
West Room, Haddon Hall 1:30 P.M.

Joseph Bertino and William L. McGuire, Presiding

1. OSTEOSARCOMA: FIVE-YEAR FOLLOW-UP OF EPIDEMIOLOGY AND TUMOR SPECIFIC TRANSFER FACTOR THERAPY. V.S. Byers, ${ }^{*}$ A. Levin, L. LeCam,* A. Hackett,* and J. Johnston,* Oakland, California. AFCR page $378 \mathrm{~A}$

2. 'MEASUREMENT OF SOLUBLE IMMUNE COMPLEXES: A GUIDE TO PROGNOSIS IN CANCER PATIENTS. R.D. Rossen,* M.A. Reisberg,* E.M. Hersch,* and J.U. Gutterman, ${ }^{*}$ Houston, Texas.

ASCI page $462 A$

3. HYPOGAMMAGLOBULINEMIA IN EXPERIMENTAL MYELOMA: THE ROLE OF SUPPRESSOR MONONUCLEAR PHAGOCYTES. R.S. Krakauer, W. Strober, and T.A. Waldmann,* Bethesda, Maryland. AFCR page $377 A$

4. CELL SURFACE ALTERATIONS DISTINCTIVE OF COLON CARCINOMA. B.D. Kahan, L.P. Rutzky,* B. Berlin,* and B.H. Tom,* Chicago, Illinois. AAP page $488 \mathrm{~A}$

5. FAMILIAL HODGKIN'S DISEASE: ASSOCIATION WITH MAJOR HISTOCOMPATIBILITY LOCI. T. Bowers, * C.F. Moldow, C.D. Bloomfield,* and E.J. Yunis, * Minneapolis, Minnesota. AFCR page 375A

6. AZATHIOPRINE AS A MUTAGEN AND CARCINOGEN. J.J. Byrnes,* K.M. Downey,* V.L. Black,* and A.G. So, Miami, Florida.

ASCI page $461 \mathrm{~A}$

7. PLASMA STEROIDS AND CLINICAL RESPONSE WITH MEDICAL ADRENALECTOMY FOR ADVANCED BREAST CARCINOMA. H.H. Newsome, Jr., P. Brown,* J. Terz,* and W. Lawrence, Jr.,* Richmond, Virginia.

AFCR page $379 A$
8. A SPECIFIC MARKER FOR PROLACTIN RESPONSIVENESS IN EXPERIMENTAL BREAST CANCER: $\alpha$-LACTALBUMIN MESSENGER RIBONUCLEIC ACID. N.J. Nardacci* and W.L. McGuire, San Antonio, Texas. ASCI page $462 A$

9. CORTICOSTEROID EFFECT ON GRANULOPOIESIS FOLLOWING CYCLOPHOSPHAMIDE. R.A. Joyce and P.A. Chervenick, ${ }^{* *}$ Pittsburgh, Pennsylvania. AFCR page $377 A$

10. RESCUE OF METHOTREXATE TOXICITY TO MOUSE BONE MARROW: A COMPARISON BETWEEN CITROVORUM FACTOR AND NUCLEOSIDES. H.M. Pinedo,* B.A. Chabner, and J.M. Bull, Bethesda, Maryland. AFCR page $380 \mathrm{~A}$

11. INHIBITION OF GROWTH OF NORMAL MURINE GRANULOCYTES BY CO-CULTURED ACUTE LEUKEMIC CELLS. A.M. Miller,* P.L. Page,* and S.H. Robinson, ** Boston, Massachusetts.

AFCR page $379 A$

12. MODULATION OF GRANULOPOIETIC ACTIVITY BY INTERACTIONS BETWEEN LYMPHOCYTES AND MONOCYTES. R.W. Bolin* and W.A. Robinson (Intr. by E. Genton), Denver, Colorado.

AFCR page $374 A$

13. DEMONSTRATION OF TWO TYPES OF COLONY STIMULATING FACTOR IN NORMAL HUMAN SERUM. T. Mahmood* and W.A. Robinson, Denver, Colorado.

AFCR page 379A 
Music Room, Chalfonte 1:30 P.M.

Jerome Brody and Donald F. Tierney, Presiding

1. MORPHOLOGICAL DETERMINANTS OF MAXIMAL EXPIRATORY FLOW IN HUMAN LUNG. D.E. Niewoehner, J. Knoke, ${ }^{*}$ and J. Kleinerman,* Cleveland, Ohio. AFCR page 388A

2. CHEMICAL AND NEURAL MECHANISMS IN ALVEOLAR HYPOVENTILATION. N. Wolkove,* M.D. Altose, ${ }^{*}$ S.G. Kelsen," and N.S. Cherniack, ${ }^{* *}$ Philadelphia, Pennsylvania. AFCR page $391 A$

3. THE CHEMICAL NATURE OF THE SURFACE SECRETION OF THE BRONCHIOLE. R. Kronenberg* and R.V. Ebert, ${ }^{* *}$ Minneapolis, Minnesota.

AAP page $489 A$

4. EFFECTS OF PROSTAGLANDIN CYCLIC ENDOPEROXIDES ON THE PULMONARY CIRCULATION AND LUNG FLUID BALANCE IN AWAKE SHEEP. R.E. Bowers, ${ }^{*}$ E.F. Ellis, ${ }^{*}$ P.J. Owen, ${ }^{*}$ K.L. Brigham, and J.A. Oates, ${ }^{* *}$ Nashville, Tennessee.

AFCR page $382 \mathrm{~A}$

5. ANALYSIS OF BRONCHO-ALVEOLAR FLUID IN PATIENTS WITH HYPERSENSITIVITY PNEUMONITIS. H.Y. Reynolds, J.D. Fulmer,* J.A. Kazmierowski,* W.C. Roberts, ${ }^{*}$ M.M. Frank, ${ }^{* *}$ and R.G. Crystal, Bethesda, Maryland. AFCR page 388A

6. CELLULAR ASPECTS OF COMPENSATORY LUNG GROWTH FOLLOWING PNEUMONECTOMY. R.E. Burki,* J.S. Brody, and N.B. Kaplan,* Boston, Massachusetts. ASCI page $464 \mathrm{~A}$

7. THE DISTRIBUTION AND CHARACTERIZATION OF TYPE III COLLAGEN IN ADULT HUMAN LUNG TISSUE. B.D. McLees,* G. Schleiter,* and S.R. Pinnell, Durham, North Carolina.

AFCR page $387 \mathrm{~A}$
8. COMPARISON OF COLLAGEN CONCENTRATION, DISTRIBUTION AND SYNTHESIS IN FIBROTIC AND NORMAL LUNGS. J.D. Fulmer,* R.S. Bienkowski,* M.J. Cowan,* K.H. Bradley,* W.C. Roberts, ${ }^{*}$ and R.G. Crystal, Bethesda, Maryland.

AFCR page 384A

9. HUMAN ALVEOLAR MACROPHAGE CHARACTERISTICS OF EXSMOKERS. J.O. Harris, G.N. Olsen, and J.R. Castle,* Gainesville, Florida.

AFCR page $386 A$

10. CESSATION OF SMOKING: EFFECT ON TRACHEOBRONCHIAL CLEARANCE OF INHALED PARTICLES. P. Werner, ${ }^{*}$ B.V. Joshi, ${ }^{*}$ R.V. Lourenco, ${ }^{* *}$ P.S. Lee, ${ }^{*}$ and F.J. Hass, ${ }^{*}$ Chicago, Illinois. AFCR page $391 A$

11. THE EFFECT OF TOBACCO SMOKE ON THE METABOLIC FUNCTIONS OF ALVEOLAR MACROPHAGES. D.B. Drath, ${ }^{*}$ A. Harper, ${ }^{*}$ M.L. Karnovsky,* and G. Huber* (Intr. By M. Raben), Boston, Massachusetts. ASCI page $464 \mathrm{~A}$

12. ELEVATION OF GRANULOMATOUS LYMPH NODE AND SERUM LYSOZYME IN SARCOIDOSIS AND CORRELATION WITH ANGIOTENSIN CONVERTING ENZYME. E. Silverstein,** J. Friedland,"* and T. Ackerman, ${ }^{*}$ Brooklyn, New York.

AFCR page 390A

13. SEROTONIN-INDUCED BRONCHOCONSTRICTION IN DOGS: INTERACTION WITH THE CHOLINERGIC NERVOUS SYSTEM. H.L. Hahn," P.D. Graf, ${ }^{*}$ and J.A. Nadel, ${ }^{* *}$ San Francisco, California. 


\section{Carolina Room, Chalfonte}

1:30 P.M.

Maurice B. Burg and Jay H. Stein, Presiding

1. MALEIC ACID-INDUCED IMPAIRMENT OF CONVERSION OF 25-HYDROXYVITAMIN $D_{3}$ TO 1,25-DIHYDROXYVITAMIN $\mathrm{D}_{3}$ IN VIVO AND IN VITRO: IMPLICATIONS FOR FANCONI'S SYNDROME. E.D. Brewer,* H.C. Tsai,* S. Szeto,* and R.C. Morris, Jr., ** San Francisco, California.

AFCR page $395 A$

2. CONTROL OF AMMONIA EXCRETION IN THE RABBIT. H.L. Yu,* R.A. Giammarco,* M.B. Goldstein, B.J. Stinebaugh, and M.L. Halperin, Toronto, Ontario, Canada.

AFCR page 417 A

3. INHIBITION OF THE ANION EXIT STEP IN URINARY ACIDIFICATION BY A DISULFONIC STILBENE. L.H. Cohen,* A. Mueller,* and P.R. Steinmetz, ** Iowa City, lowa. AFCR page 396A

4. AN EXTRARENAL ROLE FOR PARATHYROID HORMONE IN THE DISPOSAL OF ACUTE ACID LOADS. D.S. Fraley* and S. Adler, Pittsburgh, Pennsylvania. AFCR page $400 A$

5. EVIDENCE FOR A CONCENTRATION GRADIENT FAVORING OUTWARD MOVEMENT OF SODIUM FROM THE THIN LOOP OF HENLE IN NONDIURETIC RATS. P.A. Johnston, ${ }^{*}$ C.A. Battilana,* F.B. Lacy,* and R.L. Jamison, Stanford, California. ASCI page 468A

6. EFFECT OF INDOMETHACIN, A PROSTAGLANDIN SYNTHESIS INHIBITOR, AND DIETARY SODIUM CHLORIDE ON SODIUM CONCENTRATION AND PLASMA FLOW IN RENAL PAPILLA. M. Ganguli,* L. Tobian,** S. Azar, and M. O’Donnell,* Minneapolis, Minnesota. ASCI page $467 \mathrm{~A}$

7. DIRECT MEASUREMENT OF PAPILLARY COLLECTING DUCT SODIUM AND POTASSIUM TRANSPORT DURING SALINE DIURESIS IN
THE RAT: EVIDENCE FOR NEPHRON HETEROGENEITY. R.W. Osgood,* J.H. Stein, and R.T. Kunau, ${ }^{*}$ San Antonio, Texas. $\quad$ ASCI page 469A

8. PAPILLARY COLLECTING DUCT AND JUXTAMEDULLARY NEPHRON FUNCTION AFTER RELEASE OF BILATERAL URETERAL LIGATION. J. Buerkert, M. Head,* and S. Klahr, St. Louis, Missouri. AFCR page $395 A$

9. ANTIDIURETIC HORMONE ANTAGONISM ASSOCIATED WITH ACUTE RENAL ARTERY STENOSIS. O.G. Galvez,* B.W. Roberts,* W.H. Bay, ${ }^{*}$ and T.F. Ferris, Columbus, Ohio.

ASCI page $467 A$

10. ROLE OF RENAL CYCLIC ADENOSINE MONOPHOSPHATE IN THE NATRIURESIS OF VOLUME EXPANSION. R.M. Friedler,* C. Descoeudres, ${ }^{*}$ K. Kurokawa,* W.J. Kreusser,* and S.G. Massry, Los Angeles, California.

ASCI page $467 A$

11. ISOTONIC INTERCELLULAR SPACES DURING FLUID ABSORPTION COUPLED TO ACTIVE SALT TRANSPORT IN THE PARS RECTA. J.A. Schafer,* C.S. Patlak, ${ }^{*}$ and T.E. Andreoli, Birmingham, Alabama, and Bethesda, Maryland. AFCR $411 \mathrm{~A}$

12. RELATIONSHIP BETWEEN P-AMINOHIPPURATE SECRETION AND CELLULAR MORPHOLOGY IN SUPERFICIAL AND JUXTAMEDULLARY PROXIMAL TUBULES. P.B. Woodhall,* C.C. Tisher, C.A. Simonton,* and R.R. Robinson, ${ }^{* *}$ Durham, North Carolina. AFCR page $417 A$

13. LONG-TERM PREVENTION OF CALCIUM OXALATE NEPHROLITHIASIS BY CHRONIC THIAZIḌE AND ALLOPURINOL ADMINISTRATION. F.L. Coe, Chicago, Illinois. $\quad A F C R$ page $396 A$ 
Sponsored by

\section{THE AMERICAN FEDERATION FOR CLINICAL RESEARCH}

Chalfonte-Haddon Hall Hotel, LaFayette Hotel, and Ramada Inn

Atlantic City, New Jersey

SUNDAY EVENING, MAY 2, 1976

Cardiovascular III, Carolina Room, Chalfonte

Cardiovascular IV, Music Room, Chalfonte

Clinical Pharmacology, Teakwood Room, LaFayette

Dermatology, Garden Room, Haddon Hall

Endocrinology II, Rutland Room, Haddon Hall

Gastroenterology II, $\dagger$ Viking Room, Haddon Hall

Gastroenterology III, West Room, Haddon Hall

Hematology II, Windsor Room, Haddon Hall

Hematology III, Vernon Room, Haddon Hall
Immunology and Connective Tissue II, ${ }^{\dagger}$ Pennsylvania Room I, Haddon Hall

Infectious Disease II, Ramada Inn

Metabolism II, $\dagger$ Pennsylvania Room III, Haddon Hall

Pulmonary II, Solarium, Haddon Hall

Renal and Electrolytes III, $\dagger$ Pennsylvania Room II, Haddon Hall

Renal and Electrolyte Poster Session, Exhibit Hall

fFollowed by a symposium.

Cardiovascular III

Carolina Room, Chalfonte

7:30 P.M.

Robert Roberts and Douglas Zipes,

Presiding

1. LYSIS OF ACUTELY THROMBOSED AORTOCORONARY VEIN GRAFTS BY LOCAL INFUSION OF THROMBOLYSIN. E. Byrne-Quinn, L.I. Schocket,* J. Silverman,* R.G. Sanderson,* and W.C. Wilcox, ${ }^{*}$ Tucson, Arizona. page $211 \mathrm{~A}$

2. ISOPROTERENOL AS A CAUSE OF ACUTE ST ELEVATION WITHOUT MYOCARDIAL ISCHEMIA. G.R. Nelson,* S.J. Fischl,* and E.S. Kirk, Bronx, New York.

page $233 A$

3. WHAT IS THE CORONARY HEMODYNAMIC SIGNIFICANCE OF THE LENGTH OF A CORONARY ARTERY OBSTRUCTION? R.L. Feldman,* W.W. Nichols, and C.J. Pepine, Gainesville, Florida.

page $216 A$

4. PURKINJE FIBER SURVIVAL FOLLOWING HUMAN MYOCARDIAL INFARCTION. L.N. Horowitz, J.F. Spear, H. MacVaugh, III,* and E.N. Moore,** Philadelphia, Pennsylvania. page $223 \mathrm{~A}$

xxx 1976 Programs - ASCI-AFCR-AAP
5. EFFECTS OF QUINIDINE ON THE ATRIAL VULNERABLE PERIOD. A.H. Calon, * A.N. Damato,** A.R. Ticzon, * A.R. Caracta, M. Akhtar, C.P. Reddy, ${ }^{*}$ and C.R. Carambas, ${ }^{*}$ Staten Island, New York.

page $212 \mathrm{~A}$

6. CHRONIC ELECTROPHYSIOLOGICAL STUDY OF PATIENTS WITH PAROXYSMAL TACHYCARDIA. D. Wu, C. Wyndham, P. Denes, R. Miller, ${ }^{*}$ and K. Rosen, Chicago, Illinois. page $247 \mathrm{~A}$

7. ANALYSIS OF WARNING ARRHYTHMIA PRIOR TO VENTRICULAR TACHYCARDIA DURING ACUTE MYOCARDIAL INFARCTION IN MAN. D.F. Meacham, ${ }^{*}$ N. de Soyza, J. Bissett, J. Kane,* and M. Murphy, ** Little Rock, Arkansas. page $230 \mathrm{~A}$

8. EFFECTS OF VERAPAMIL ON CARDIAC PERFORMANCE IN CONSCIOUS DOGS. R.K. Newman," E.J. Leroux,* D.F. Peterson,* V.S. Bishop," and L.D. Horwitz, San Antonio, Texas. page $233 A$ 
9. THE ORIGINS OF LATE VENTRICULAR RHYTHMS AND THEIR ACTIVATION PATTERNS IN EXPERIMENTAL SEPTAL INFARCTION IN DOGS. E.L. Michelson, S.R. Spielman,* J.F. Spear, and E.N. Moore,** Philadelphia, Pennsylvania.
10. DIGITALIS IN BI- AND TRIFASCICULAR CONDUCTION DISEASE: ITS EFFECT ON THE HV INTERVAL. S. Kauffman, ${ }^{*}$ J.H. McAnulty, ${ }^{*}$ H. DeMots, ${ }^{*}$ E. Murphy,* and S.H. Rahimtoola,** Portland, Oregon. page $224 \mathrm{~A}$
Music Room, Chalfonte 7:30 P.M.

Albert Most and Suzanne Oparil, Presiding

1. IDENTIFICATION OF DOUBLE OUTLET RIGHT VENTRICLE BY TWO-DIMENSIONAL ECHOCARDIOGRAPHY. W.L. Henry, B.J. Maron,* J.M. Griffith,* and S.E. Epstein, Bethesda, Maryland.

page $222 \mathrm{~A}$

2. CONTINUOUS VENTRICULAR DIMENSIONS IN MAN DURING SUPINE BICYCLE EXERCISE AND RECOVERY. R.A. Stein,* D. Michielli,* E. Fox,* M. Sloan,* and N. Krasnow,** Brooklyn, New York. page $241 A$

3. EVALUATION OF GLOBAL AND REGIONAL FUNCTION FOLLOWING VENTRICULOGRAPHY BY ISOVOLUMIC AND EJECTION PHASE INDICES. V.S. Mathur, P.R. Hernandez-Lattuf, E. Garcia,* P.J. Hogan,* and R.J. Hall,* Houston, Texas.

page $229 A$

4. COMPARISON OF REGIONAL MYOCARDIAL FLOW MEASUREMENTS WITH SCINTILLATION CAMERA DETECTION OF XENON-133 AND RADIOACTIVE MICROSPHERES. S.M. Morgan,* J.D. Fisher,* and L.D. Horwitz (Intr. by R.N. Schnitzler), San Antonio, Texas. page $232 \mathrm{~A}$

5. REDISTRIBUTION OF THALLIUM-201 FOLLOWING TRANSIENT MYOCARDIAL ISCHEMIA. G.M. Pohost, G.A. Beller, R.H. Moore, ${ }^{*}$ K.A. McKusick,* and L.M. Zir,* Boston, Massachusetts.

page $235 A$
6. REPRODUCIBILITY AND RELIABILITY OF THALLIUM-201 MYOCARDIAL IMAGING. P. McLaughlin,* R. Martin,* S. Daspit,* M. Goris, ${ }^{*}$ W. Haskell,* S. Lewis,* P. Doherty,* D. Harrison, ** and J. Kriss, ${ }^{* *}$ Stanford, California. page $230 \mathrm{~A}$

7. EVALUATION OF MYOCARDIAL SCAR: ANGIOGRAPHIC AND PATHOLOGIC CORRELATES IN AN ANIMAL MODEL. B. Haider, C. Lee, ${ }^{*}$ M. Ahmad,* and T.J. Regan,** Newark, New Jersey, page $220 \mathrm{~A}$

8. INFARCT SIZING IN AWAKE, UNSEDATED DOGS WITH ACUTE ANTERIOR MYOCARDIAL INFARCTS. L. Poliner, * L.M. Buja, E.M. Stokely,* R.W. Parkey, ${ }^{*}$ M.J. Stone, F.J. Bonte, ${ }^{*}$ and J.T. Willerson, Dallas, Texas. page $235 A$

9. LEFT VENTRICULAR WALL MOTION IN SUBENDOCARDIAL INFARCTION EVALUATED BY ECHOCARDIOGRAPHY. S. Rasmussen,* B.C. Corya, ${ }^{*}$ H. Feigenbaum, ${ }^{* *}$ and S.B. Knoebel, ${ }^{* *}$ Indianapolis, Indiana.

page $237 A$

10. DIRECT NONINVASIVE EVALUATION OF MECHANISM OF ACTION OF CARDIOSELECTIVE BETA BLOCKING AGENTS IN PATIENTS WITH ANGINA PECTORIS USING EXERCISE RUBIDIUM-81 MYOCARDIAL IMAGING. A.F. Salel, D. Berman,* G. DeNardo, ${ }^{* *}$ and D.T. Mason, ${ }^{* *}$ Davis, California.

page $239 \mathrm{~A}$ 
Teakwood Room, LaFayette

$$
\text { 7:30 P.M. }
$$

Lewis Landsberg and W.L. Thompson, Presiding

1. CLINICAL EFFICACY OF NITROPRUSSIDE IN REDUCING EXTENT OF ISCHEMIC INJURY AND IMPROVING PUMP FUNCTION IN ACUTE MYOCARDIAL INFARCTION: EVALUATION BY PRECORDIAL ST SEGMENT MAPPING AND CARDIAC CATHETERIZATION. N.A. Awan,* R.R. Miller, Z. Vera, A.N. DeMaria, E.A. Amsterdam and D.T. Mason, ${ }^{* *}$ Davis, California. page $251 \mathrm{~A}$

2. CATECHOL METABOLISM IN RAT INTESTINAL MUCOSA: A MAJOR ROUTE INVOLVING GLUCURONIDATION. L. Landsberg, M.B. Berardino,* J.B. Young, * and J. Stoff, Boston, Massachusetts.

page $256 \mathrm{~A}$

3. CATECHOLAMINE CLEARANCE BY THE ISOLATED PERFUSED RAT KIDNEY: PREFERENTIAL EXCRETION AND METABOLISM OF EPINEPHRINE. P. Silva, A. Besarab, and L. Landsberg, Boston, Massachusetts.

page $258 \mathrm{~A}$

4. INDEPENDENT MODULATION OF RENAL CORTICAL CYCLIC ADENOSINE MONOPHOSPHATE AND CYCLIC GUANOSINE MONOPHOSPHATE CONTENT BY CYCLIC NUCLEOTIDE PHOSPHODIESTERASE. T.V. Zenser, P.A. Craven,* F.R. DeRubertis, and B.B. Davis, Pittsburgh, Pennsylvania. page $260 \mathrm{~A}$
5. ANTIPYRINE AND INDOCYANINE GREEN AS INDICATORS OF DRUG DISPOSITION DURING ACUTE VIRAL HEPATITIS. R.L. Williams, ${ }^{*}$ T.F. Blaschke, P.J. Meffin, ${ }^{*}$ K.L. Melmon, and M. Rowland,* San Francisco and Palo Alto, California, and Manchester, England. page 259A

6. PHARMACOKINETICS OF DIGOXIN IN THE RABBIT. H. Ochs,* G. Bodem,* B. Louven,* G. Bahles,* D.J. Greenblatt, and T.W. Smith, Bonn, Germany, and Boston, Massachusetts. page 257A

7. CORRELATION OF PROPRANOLOL PLASMA LEVEL WITH EFFECT IN PATIENTS WITH ESSENTIAL TREMOR. R.G. McAllister, Jr., R.W. Ware, ${ }^{*}$ W.R. Markesbery, ${ }^{*}$ and S.M. Howell, ${ }^{*}$ Lexington, Kentucky. page $257 \mathrm{~A}$

8. STABLE ISOTOPE-MASS SPECTROMETRIC MEASUREMENT OF L-DOPA METABOLISM IN RAT BRAIN. C.R. Freed* and R.C. Murphy* (Intr. by C.A. Chidsey**), Denver, Colorado. page $254 \mathrm{~A}$

9. DPAVP(1-DEAMINO-[2-PHENYLALANINE, 8 ARGININE]-VASOPRESSIN): A VASOPRESSIN ANALOG WITH SELECTIVE MICROVASCULAR ACTIONS FOR THE TREATMENT OF CIRCULATORY SHOCK. B.M. Altura, Brooklyn, New York. page $250 \mathrm{~A}$

10. ACTIVE UPTAKE OF ${ }^{3}$ H-PROPRANOLOL BY ISOLATED ALVEOLAR MACROPHAGES. R.E. Vestal, D.M. Kornhauser,"* and D.G. Shand, Nashville, Tennessee.

page $259 \mathrm{~A}$
Garden Room, Haddon Hall 7:30 P.M.

Eugene Bauer and Lowell Goldsmith, Presiding

1. SYNTHESIS OF PROCOLLAGEN AND ELASTIN BY EMBRYONIC AORTA CELLS. J. Uitto* and D.J. Prockop,** St. Louis, Missouri, and Piscataway, New Jersey.

page $268 A$

2. PREPARATION AND ULTRASTRUCTURAL FEATURES OF THE HUMAN CUTANEOUS BASEMENT MEMBRANE-ANCHORING FIBRIL COMPLEX. M.R. Heaphy* and R.K. Winkelmann,** Rochester, Minnesota.

page $263 \mathrm{~A}$

3. CONTROL OF HYALURONIC ACID ACCUMULATION IN DERMAL FIBROBLASTS. S.I. Lamberg and N.J. Joseph, * Baltimore, Maryland. page $265 A$

4. XERODERMA PIGMENTOSUM FIBROBLASTS' POST-ULTRAVIOLET COLONY-FORMING ABILITY REFLECTS THE PATIENT'S NEUROLOGI-
CAL STATUS. A.D. Andrews, ${ }^{*}$ S.F. Barrett,* and J.H. Robbins, ** Bethesda, Maryland. page $260 A$

5. STAPHYLOCOCCAL EXFOLIATIN METABOLISM IN NEONATAL AND ADULT MICE. P. Fritsch,* P.M. Elias, * and J. Vargas* (Intr. by W.L. Epstein), New Haven, Connecticut, and San Francisco, Cali fornia. page $263 \mathrm{~A}$

6. IMMUNOELECTRONMICROSCOPIC LOCALIZATION OF IMMUNOGLOBULIN A IN SKIN OF PATIENTS WITH DERMATITIS HERPETIFORMIS. H. Yaoita* and S.I. Katz, Bethesda, Maryland.

page $268 A$

7. HERPES GESTATIONIS: CHARACTERIZATION OF HG FACTOR. G. Tappeiner, * K.G. Heine, ${ }^{*}$ and R.E. Jordon, Rochester, Minnesota. page $268 \mathrm{~A}$

8. IN VITRO AND IN VIVO CHARACTERIZATION OF HUMAN MELANOMA CELLS. A.A. Creasey,* A. Hackett, ${ }^{*}$ H. Smith, ${ }^{*}$ K. Fukuyama, ${ }^{* *}$ and W. Epstein,** Oakland and San Francisco, California.

page $262 A$ 
9. ISOLATION OF SUBSTRATES FOR EPIDERMAL TRANSGLUTAMINASE FROM BOVINE EPIDERMIS. M.M. Buxman, G.E. Buehner, ${ }^{*}$ and K.D. Wuepper, Portland, Oregon.

page $262 A$
10. HUMAN EPIDERMAL RIBONUCLEASES. B. Brant,* S.W. Melbye,* and I.M. Freedberg, Boston, Massachusetts. page $261 \mathrm{~A}$

\section{Endocrinology}

\section{Rutland Room, Haddon Hall 7:30 P.M. \\ Daryl Granner and John Wilber, Presiding}

1. DISPARATE REGULATION OF THE PROLACTIN RECEPTOR IN LIVER AND MAMMARY GLAND. J.I. Stagner,* J. Cyrus,* and B.M. Sherman, Iowa City, Iowa. page $278 \mathrm{~A}$

2. RESPONSE OF PLASMA ADRENOCORTICOTROPIC HORMONE TO THYROTROPIN RELEASING FACTOR, VASOPRESSIN OR HYPOGLYCEMIA IN CUSHING'S DISEASE AND NELSON'S SYNDROME. M. Luria* and D.T. Krieger, ${ }^{* *}$ New York, New York. page $274 A$

3. PITUITARY FUNCTION AND STRUCTURE WITH INCREASING THYROID IMPAIRMENT. E.C. Ridgway, S.T. Bigos, ${ }^{*}$ I.A. Kourides, and F. Maloof, ** Boston, Massachusetts.

page $277 A$

4. DIRECT IDENTIFICATION OF ECTOPIC $\beta$ ADRENERGIC RECEPTOR BINDING SITES IN AN ADRENAL CARCINOMA WITH $(-)\left[{ }^{3} \mathrm{H}\right]$ DIHYDROALPRENOLOL. L.T. Williams, * T.B. Gore, ${ }^{*}$ and R.J. Lefkowitz, Durham, North Carolina. page $280 \mathrm{~A}$

5. "PERMISSIVE" EFFECT OF GLUCOCORTICOIDS ON PORPHYRIN FORMATION IN CULTURED CHICK EMBRYO LIVER CELLS. S.E. Lane, ${ }^{*}$ A.S. Gidari,* and R.D. Levere, ${ }^{* *}$ Brooklyn, New York. page $274 \mathrm{~A}$

6. RECIPROCAL CHANGES IN SERUM TRIIODOTHYRONINE AND REVERSE SERUM TRIIODOTHYRONINE INDUCED BY ALTERING
THE CARBOHYDRATE CONTENT OF THE DIET. E. Danforth, Jr., E.D. Tyzbir,* E.S. Horton,** E.A.H. Sims, ${ }^{* *}$ A.G. Burger, L.E. Braverman, ${ }^{* *}$ A.G. Vagenakis, and S.H. Ingbar,** Burlington, Vermont; Geneva, Switzerland; Worcester and Boston, Massachusetts. page $271 \mathrm{~A}$

7. THE EFFECT OF VARYING SERUM THYROXINE CONCENTRATIONS ON EXTRATHYROIDAL PRODUCTION OF SERUM TRIIODOTHYRONINE, REVERSE SERUM TRIIODOTHYRONINE, AND 3-3' DIIODOTHYRONINE. K.D. Burman, R.C. Dimond, R.A. McGuire,* J.M. Earll,** D. Strum,* and L. Wartofsky, Washington, D.C., and Bethesda, Maryland.

page $270 \mathrm{~A}$

8. IN UTERO TREATMENT OF FETAL GOITER WITH A NON-HALOGENATED THYROXINE ANALOG. F. Comite,* G.N. Burrow, and E.C. Jorgensen,* New Haven, Connecticut, and San Francisco, California.

page $271 A$

9. THYROID HORMONE STIMULATES FORMATION OF MESSENGER RIBONUCLEIC ACID AND POLY-A-CONTAINING NUCLEAR RIBONUCLEIC ACID. W.H. Dillmann,* J. Mendecki,* D. Koerner, ${ }^{*}$ H.L. Schwartz, ${ }^{*}$ U. Thakare,* and J.H. Oppenheimer, ${ }^{* *}$ Bronx, New York.

page $271 A$

10. IMPORTANCE OF THE INTRACELLULARLY FORMED TRIIODOTHYRONINE IN THE REGULATION OF CELL METABOLISM. S. Refetoff, F. Delange, ${ }^{*}$ H. Berquist,* V.S. Fang, ${ }^{*}$ V. Van Humskerke, ${ }^{*}$ H. Seo,* and A.M. Ermans, ${ }^{*}$ Chicago, Illinois; Brussels, Belgium; and Zaire.

page $276 A$ 


\author{
Viking Room, Haddon Hall \\ 7:30 P.M. \\ Allan Cooke and Michael Levitt, \\ Presiding
}

1. REGULATION OF RAT PROXIMAL SMALL INTESTINAL ENZYME ACTIVITY BY ILEAL GLUCOSE PERFUSION. J. Espinoza,* S.B. Clark, ${ }^{*}$ A. Hritz, ${ }^{*}$ and N.S. Rosensweig, New York, New York. page $283 \mathrm{~A}$

2. IDENTIFICATION OF TWO DISTINCT CHOLECYSTOKININ RECEPTORS IN PANCREATIC ACINAR CELLS. B.W. Long* and J.D. Gardner, Bethesda, Maryland. page $287 \mathrm{~A}$

3. INTESTINAL ABSORPTION OF LEUCINE FROM DI-, TRI- AND TETRAPEPTIDES IN RATS. Y.C. Chung,* D.B.A. Silk, ${ }^{*}$ and Y.S. Kim, ${ }^{* *}$ San Francisco, California. page $282 \mathrm{~A}$

4. EFFECT OF CELIAC SPRUE ON FOLATE DIGESTION AND ABSORPTION.C.H. Halsted, D. Cantor,* A. Reisenauer,* and J. Romero,* Davis, California. page $285 A$

5. INFECTION AND IMMUNITY IN AN ANIMAL MODEL OF GIARDIASIS. D.P. Stevens, I.C. Roberts-Thomson,* A.A.F. Mahmoud, and K.S. Warren, Cleveland, Ohio.

page $292 A$

6. STRUCTURE-ACTIVITY RELATIONS OF SECRETIN: BIOLOGICAL EFFECTIVENESS OF CTERMINAL SEQUENCES. M. Schebalin,* M.L. Fink, ${ }^{*}$ M. Bodanszky, ${ }^{*}$ and G.M. Makhlouf, ** Richmond, Virginia, and Cleveland, Ohio. page $290 \mathrm{~A}$
7. IMPAIRED RELEASE OF SECRETIN IN CELIAC SPRUE. R.A. Rhodes,* W.Y. Chey, ${ }^{* *}$ H.H. Tai,* and R. Escoffery,* Rochester, New York.

page $290 \mathrm{~A}$

8. SOMATOSTATIN SUPPRESSES MEAL-STIMULATED PANCREATIC SECRETIONS. R.M. Wilson,* G. Boden, ${ }^{* *}$ N. Essa-Koumar, ${ }^{*}$ and L.S. Shore,* Philadelphia, Pennsylvania, and Piscataway, New Jersey.

page $293 \mathrm{~A}$

\section{Symposium \\ "The Gastrointestinal Sphincter"}

Moderator: Allan R. Cooke

Participants:

1. WHAT IS A SPHINCTER? James Christensen, University of Iowa, Iowa City, Iowa.

2. THE LOWER ESOPHAGEAL SPHINCTER IN VITRO. David J. deCarle, University of Iowa, Iowa City, Iowa.

3. THE LOWER ESOPHAGEAL SPHINCTER IN VIVO. Jose Behar, Yale University, New Haven, Connecticut.

\section{Gastroenterology III}

\section{West Room, Haddon Hall 7:30 P.M.}

Peter Loeb and Francis Simon, Presiding

1. LONG CHAIN ACYL-COENZYME A INHIBITION OF HEPATIC ACETYL-COENYZME A CARBOXYLASE: MODULATION BY CYTOPLASMIC PROTEINS. M.R. Lunzer,* J.A. Manning,* and R.K. Ockner, San Francisco, California. page $287 \mathrm{~A}$

2. EFFECT OF FASTING AND PHENOBARBITAL ON HEPATIC URIDINE DIPHOSPHATE-GLUCURONIC ACID METABOLISM. B.F. Felsher, N.M. Carpio,* and K. VanCouvering,* Long Beach, California. page $284 A$

3. THE ORIGIN OF CHYLOMICRON LECITHIN. C.M. Mansbach, II, Durham, North Carolina.

page $288 \mathrm{~A}$
4. EFFECT OF PHENOBARBITAL AND THYROIDECTOMY ON HEPATIC (Na-K)-ADENOSINE TRIPHOSPHATASE ACTIVITY AND BILE FLOW. F.R. Simon, E. Sutherland,* J. Cersonsky,* and L. Accatino, ${ }^{*}$ Denver, Colorado. page $291 A$

5. CHARACTERISTIC PLASMA AMINO ACID ABNORMALITIES IN THE ALCOHOLIC: RESPECTIVE ROLES OF ALCOHOLISM, NUTRITION AND LIVER INJURY. S. Shaw* and C.S. Lieber,** Bronx and New York, New York. page $291 \mathrm{~A}$

6. PREVENTION OF HB Ag CARRIER STATE IN NEONATES BY LARGE DOSES OF CONVENTIONAL GAMMA GLOBULIN. R.R. Varma,* Milwaukee, Wisconsin. page $292 A$ 
7. SELECTIVE EFFECTS OF VASOPRESSIN ON CANINE SPLANCHNIC CIRCULATIONS. J.C. Kerr,* D.G. Reynolds, ${ }^{* *}$ and K.G. Swan, ${ }^{* *}$ Newark, New Jersey. page $287 \mathrm{~A}$

8. DIAGNOSIS OF BACTERIAL OVERGROWTH OR ILEAL DYSFUNCTION IN CHILDREN BY USE
OF A STABLE ISOTOPE BREATH TEST, ${ }^{13} \mathrm{C}$ GLYCOCHOLATE. N.W. Solomons, * D. Schoeller,* J. Wagonfeld,* D. Ott,* F. Viteri,* P. Klein,* and I. Rosenberg, Chicago and Argonne, Illinois; Los Alamos, New Mexico; and Guatemala City, Guatemala. page $291 \mathrm{~A}$
Windsor Room, Haddon Hall 7:30 P.M.

Jose Corcino and B.G. Forget, Presiding

1. BETA-ADRENERGIC MODULATION OF IN VITRO ERYTHROPOIESIS. J.E. Brown* and J.W. Adamson, Seattle, Washington. page $304 \mathrm{~A}$

2. POTENTIATION OF ERYTHROPOIESIS IN VITRO BY THYROID HORMONES. D.W. Golde, N. Bersch, ${ }^{*}$ I.J. Chopra, and M.J. Cline, ${ }^{* *}$ Los Angeles, California. page $309 A$

3. THE ROLE OF CYCLIC ADENOSINE MONOPHOSPHATE IN REGULATING HEMIN-CONTROLLED REPRESSOR ACTIVITY IN INTACT RABBIT RETICULOCYTES. M.L. Freedman, J.M. Wildman,* and J. Rosman,* New York, New York. page $308 \mathrm{~A}$

4. DISSOCIATION OF ERYTHROID MATURATION AND HEMOGLOBIN SYNTHESIS IN ERYTHROLEUKEMIA CELLS. B.P. Alter* and S.C. Goff* (Intr. by A.B. Deisseroth), Boston, Massachusetts. page $302 A$

5. LOW TITER COLD HEMAGGLUTININ DISEASE: MECHANISM OF HEMOLYSIS AND RESPONSE TO HIGH DOSE CORTICOSTEROIDS. A.D. Schreiber, B. Herskowitz,* and M. Goldwein,* Philadelphia, Pennsylvania.

page $319 A$
6. HEREDITARY HEMOLYTIC ANEMIA ASSOCIATED WITH ERYTHROCYTE POTASSIUM LOSS AND DEHYDRATION: A FAMILY STUDY. B.E. Glader, N.L. Fortier and L.M. Snyder, Boston and Worcester, Massachusetts.

page $309 A$

7. CORRECTION OF IMPAIRED ERYTHROCYTE HEXOSE MONOPHOSPHATE SHUNT METABOLISM IN LIVER DISEASE BY NICOTINAMIDE ADENINE DINUCLEOTIDE PHOSPHATE. J.R. Smith,* N.E. Kay,* A.J. Gottlieb, and F.O. Oski, Syracuse, New York.

page $320 \mathrm{~A}$

8. MECHANISM OF HEPATOCYTE RELEASE OF VITAMIN $B_{12}$ INTO PLASMA. J.F. Kolhouse* and R.H. Allen, St. Louis, Missouri.

page $312 A$

9. CELLULAR FLUX AND COUNTERFLUX OF VITAMIN B 12 . R.A. Gams and F. Ostroy,* Birmingham, Alabama. page $308 \mathrm{~A}$

10. OXYGEN EQUILIBRIUM STUDIES OF HEMOGLOBIN HOPE. M.H. Steinberg, B.J. Dreiling, and J.G. Adams, Jackson, Mississippi, and Chicago, Illinois. 
Vernon Room, Haddon Hall 7:30 P.M.

John Adamson and John Hutton, Presiding

1. ACTIVATION OF HUMAN FACTOR VIII/VON WILLEBRAND FACTOR GLYCOPROTEIN. H.R. Gralnick, B.S. Coller, and J. Fenton, II,* Bethesda, Maryland, and Albany, New York. page 310A

2. CIRCULATING INHIBITORS OF BLOOD COAGULATION DIRECTED AGAINST COMPONENTS OF THE CONTACT PHASE AND PROTHROMBIN ASSOCIATED WITH PROCAINAMIDE-INDUCED LUPUS ERYTHEMATOSUS. S. Davis, B.C. Furie,* J.H. Griffin,* R. Willey,* and B. Furie, Boston, Massachusetts, and La Jolla, California. page $306 \mathrm{~A}$

3. THE INHIBITION OF HUMAN ACTIVATED HAGEMAN FACTOR BY HUMAN ANTI-THROMBIN-HEPARIN COFACTOR. N.W. Stead,* A.P. Kaplan, and R.D. Rosenberg* (Intr. by P.A. McKee), Boston, Massachusetts, and Bethesda, Maryland.

page $321 \mathrm{~A}$

4. COVALENT MODIFICATION OF AN ADENOSINE DIPHOSPHATE RECEPTOR IN HUMAN PLATELET MEMBRANES. J.S. Bennett,* W. Figures,* R.F. Colman,* and R.W. Colman, Philadelphia, Pennsylvania, and Newark, Delaware.

page $303 A$

5. HUMAN PLATELET MEMBRANE RECEPTOR FOR IMMUNE COMPLEXES: ISOLATION OF RE-
CEPTOR FOR IMMUNOGLOBULIN G Fc FRAGMENT BY AFFINITY CHROMATOGRAPHY. J. Hawiger, C.M. Cheng,* and S. Timmons,* Nashville, Tennessee.

page $310 \mathrm{~A}$

6. RADIOIMMUNOASSAY OF HUMAN PLASMA THROMBOPLASTIN ANTECEDENT. H. Saito and G. Goldsmith,* Cleveland, Ohio. page $318 \mathrm{~A}$

7. RISTOCETIN PRECIPITATION TEST: A NEW SIMPLE AND SENSITIVE TEST FOR DETECTION OF FIBRIN MONOMER AND FIBRIN DEGRADATION PRODUCTS IN PLASMA. K. Watanabe* and J.L. Tullis* (Intr. by C.A. Alper), Boston, Massachusetts.

page $322 A$

8. BIOCHEMICAL MECHANISM OF RISTOCETIN INDUCED AGGLUTINATION OF PLATELETS. B.S. Coller and H.R. Gralnick, Bethesda, Maryland. page $305 A$

9. DISSOCIATION OF FACTOR VIII IN THE PRESENCE OF PROTEOLYTIC INHIBITORS AND PREVENTION OF RE-AGGREGATION BY $0.002 \mathrm{M}$ $\mathrm{CaCl}_{2}$. I.I. Sussman* and H.J. Weiss, ${ }^{* *}$ Jamaica and New York, New York. page $321 \mathrm{~A}$

10. EFFECT OF ALTERING FIBRINOGEN CONCENTRATION ON RATE OF FIBRINOGEN SYNTHESIS IN RABBITS. B.M. Alving,* W.R. Bell,* and B.L. Evatt, Baltimore, Maryland. page $302 \mathrm{~A}$

\section{Pennsylvania Room I}

7:30 P.M.

Roger D. Rossen and Ralph Snyderman, Presiding

1. DIFFERENTIAL EFFECTS OF DEXAMETHASONE ADMINISTRATION ON SUBPOPULATIONS OF EFFECTOR CELLS MEDIATING CELLULAR CYTOTOXICITY IN HUMANS. J.E. Parrillo* and A.S. Fauci, Bethesda, Maryland. page 334A

2. CORTICOSTEROIDS IN HUMAN LYMPHOCYTEMEDIATED CYTOTOXIC REACTIONS. J.E. Balow, G.W. Hunninghake, ${ }^{*}$ and A.S. Fauci, Bethesda, Maryland. page $325 \mathrm{~A}$
3. ANTIBODY-DEPENDENT CELLULAR CYTOTOXICITY IN AUTOIMMUNITY. M.J. Becker,* J.L. Feldman,* H. Moutsopoulos, ${ }^{*}$ K. Fye, ${ }^{*}$ and N. Talal, San Francisco, California.

page $325 A$

4. PROLIFERATIVE RESPONSES OF HUMAN PERIPHERAL BLOOD LYMPHOCYTES TO MURINE B CELL MITOGENS. R.R. Rich and J.M. Chandler,* Houston, Texas. 
5. LOW FREQUENCY OF HLA-B27 IN AMERICAN BLACKS WITH ANKYLOSING SPONDYLITIS. M.A. Khan,* W.E. Braun,** and I. Kushner,** Cleveland, Ohio.

page $331 A$

6. EFFECT OF ENDOTOXIN ON THE IMMUNE SYSTEM IN MAN. R.P. Gale, G. Opelz, and D.W. Golde, Los Angeles, California.

page $327 A$

7. ABSENT SUPPRESSOR CELLS AND AUTOIMMUNITY IN HYPOGAMMAGLOBULINEMIA. D.L. Nelson, ${ }^{*}$ R.M. Blaese, W. Strober, A.R. Page,* and T.A. Waldmann, Bethesda, Maryland, and Minneapolis, Minnesota.

page $333 A$

8. POSSIBLE ROLE OF CYCLIC ADENOSINE MONOPHOSPHATE IN THE ANTI-INFLAMMATORY EFFECTS OF ALCOHOL. J.P. Atkinson, T.J. Sullivan, and C.W. Parker, ${ }^{* *}$ St. Louis, Missouri.

page $324 A$

\section{Symposium}

"Macrophages and Tumor Immunity"

Moderator: Ralph Snyderman

Participants:

1. ROLE OF MACROPHAGES IN TUMOR IMMUNITY IN VIVO. H.S. Shin, Johns Hopkins University, Baltimore, Maryland.

2. MACROPHAGE-MEDIATED TUMOR CYTOTOXICITY IN VITRO. W.H. Churchill, Harvard Medical School, Boston, Massachusetts.

3. A MECHANISM BY WHICH NEOPLASMS MAY ESCAPE IMMUNE SURVEILLANCE. R. Snyderman, Duke University Medical Center, Durham, North Carolina.

\section{Ramada Inn \\ 7:30 P.M. \\ Merle Sande and Fred Sparling, Presiding}

1. A HEURISTIC APPROACH TO HOSPITALACQUIRED PNEUMONIA. J.P. O'Keefe,* J.G. Bartlett, F.P. Tally, and S.L. Gorbach, Boston, Massachusetts.

page $350 \mathrm{~A}$

2. MECHANISMS OF IMPAIRMENT OF PULMONARY ANTIBACTERIAL DEFENSES INDUCED BY STRESS. G. Huber and J. Mullane, Boston, Massachusetts.

page $345 \mathrm{~A}$

3. INHIBITION OF HUMAN BACTERICIDAL ACTIVITY BY GONOCOCCAL ENDOTOXIN. P.A. Rice,* D.L. Kasper, and C. Solstad,* Boston, Massachusetts.

page $352 A$

4. PROTECTION AGAINST FATAL ESCHERICHIA COLI AND KLEBSIELLA BACTEREMIA FOLLOWING PNEUMOCOCCAL IMMUNIZATION. L.S. Young, Los Angeles, California. page 355A

5. IMMUNOGLOBULIN G ANTIBODIES AGAINST TYPE SPECIFIC PSEUDOMONAS LIPOPOLYSACCHARIDES DETECTED BY RADIOIMMUNOASSAY. R. Kohler,* H.B. Devlin,* M.W. Fisher,* and A. White, ${ }^{* *}$ Detroit, Michigan, and Indianapolis, Indiana.

page $347 A$
6. PRELIMINARY RESULTS OF A TRIAL OF PNEUMOCOCCAL POLYSACCHARIDE VACCINE. H.E. Krause* and M.A. Mufson,** Chicago, Illinois.

page $348 A$

7. DETECTION OF ANTIBODIES TO BACTEROIDES FRAGILIS IN PATIENTS BY RADIOIMMUNOASSAY. W.L. Hoppes, J.W. Smith,* J.P. Rissing, ${ }^{*}$ and A.C. White, ${ }^{* *}$ Indianapolis, Indiana.

page $345 \mathrm{~A}$

8. COUNTERCURRENT IMMUNOELECTROPHORESIS IN ASEPTIC MENINGITIS. R.L. Brown,* F.L. Garrity,* F. Meglio,* and S.H. Zinner, Providence, Rhode Island.

page $341 \mathrm{~A}$

9. TOXOPLASMOSIS AND SUPPRESSION OF GRANULOMATOUS HYPERSENSITIVITY. A.A.F. Mahmoud, G.T. Strickland, and K.S. Warren,** Cleveland, Ohio, and Bethesda, Maryland.

page $349 \mathrm{~A}$

10. THE ROLE OF THE SYMPATHETIC NERVOUS SYSTEM IN THE GENERALIZED SHWARTZMAN REACTION. W.K. Bolton and N.O. Atuk, Charlottesville, Virginia.

page $341 \mathrm{~A}$

1976 Programs $\cdot$ ASCI-AFCR-AAP xxxvii 
Pennsylvania Room III, Haddon Hall 7:30 P.M.

Coy D. Fitch and Phillip Poffenbarger, Presiding

1. SURFACE RECEPTOR CHANGES IN DIABETIC RATS. V. Chandramouli,* J.S. Marshall, ${ }^{* *}$ and J.R. Carter, Jr., ${ }^{* *}$ Cleveland, Ohio. page $358 \mathrm{~A}$

2. RELATIONSHIP OF INSULIN BINDING TO FUNCTION IN CULTURED EMBRYONIC HEART CELLS. A.C. Santora,* F.B. Wheeler, ${ }^{*}$ and L.J. Elsas, Atlanta, Georgia. page $369 \mathrm{~A}$

3. HYPERGLUCAGONEMIA IN STARVATION: KEY ROLE OF DECREASED HORMONAL CATABOLISM. R. Sherwin, M. Fisher, ${ }^{*}$ R. Hendler, ${ }^{*}$ and P. Felig, New Haven, Connecticut. page $370 \mathrm{~A}$

4. SUBMAXILLARY GLAND HYPERGLYCEMIC FACTOR IN MAN AND ANIMALS: AN EXTRAPANCREATIC GLUCAGON. A.M. Lawrence, L. Kirsteins,* S. Hojvat,* L. Rubin,* J. Mitton,* S. Pearce,* and R. Kacherian,* Hines and Maywood, Illinois.

page $364 \mathrm{~A}$

5. GLUCAGON AND KETOGENESIS IN ACUTE DIABETES. U. Keller,* J.L. Chiasson,* J.E. Liljenquist, A.D. Cherrington, ${ }^{*}$ A.S. Jennings, ${ }^{*}$ and O.B. Crofford,** Nashville, Tennessee. page $363 \mathrm{~A}$

6. METABOLIC ASPECTS OF ALCOHOLIC KETOACIDOSIS. R.E. Heinig, ${ }^{*}$ P.D. Miller, ${ }^{*}$ and C. Waterhouse, ${ }^{* *}$ Rochester, New York. page $362 \mathrm{~A}$
7. GASTRIC INHIBITORY POLYPEPTIDE RELEASE AFTER ORAL GLUCOSE AND QUANTIFICATION OF ITS ROLE IN INSULIN SECRETION IN STATES OF GLUCOSE INTOLERANCE. D.K. Andersen,* J.D. Tobin, and R. Andres, ${ }^{* *}$ Baltimore, Maryland. page $355 \mathrm{~A}$

8. MYOINOSITOL AND NERVE CONDUCTION VELOCITIES FOLLOWING RENAL TRANSPLANTATION. R.S. Clements, Jr., A.G. Diethelm, and S.J. Oh, * Birmingham, Alabama. page $358 \mathrm{~A}$

\section{Symposium}

"Disease of Skeletal Muscle"

Moderator: Coy D. Fitch

Participants:

1. METABOLIC ADAPTATION OF SKELETAL MUSCLE. John O. Holloszy, Washington University, St. Louis, Missouri.

2. SIGNIFICANCE OF ABNORMALITIES OF CREATINE METABOLISM. Coy D. Fitch, St. Louis University, St. Louis, Missouri.

3. THE MUSCLE CELL IN CHRONIC ALCOHOLISM. James P. Knochel, University of Texas Southwestern Medical School at Dallas, Dallas, Texas.
Solarium, Haddon Hall 7:30 P.M.

W.G. Johanson, Jr., and Paul Stevens, Presiding

1. THE RELATIONSHIP BETWEEN SITE OF FLOW LIMITATION AND MECHANISMS OF OBSTRUCTION IN EXERCISE INDUCED ASTHMA. R.L. Haynes, * J.J. Wellman, * R.H. Ingram, Jr., and E.R. McFadden, Jr., Boston, Massachusetts. page $386 \mathrm{~A}$

2. THE EFFECT OF DEEP INSPIRATION ON MAXIMUM EXPIRATORY FLOW RATES IN ASTHMATIC SUBJECTS. J.E. Fish,* T.J. Kehoe, ${ }^{*}$ and D.W. Cugell,** Chicago, Illinois. page $384 \mathrm{~A}$

3. PULMONARY LYMPH: SMOOTH-MUSCLE CONTRACTING ACTIVITY AND ITS INCREASE DURING HYPOXIC VENTILATION IN DOGS. $\mathrm{N}$. Hara and S.I. Said,** Dallas, Texas. page $385 \mathrm{~A}$
4. PULMONARY CONGESTION FOLLOWING RAPID SALINE INFUSION. R.F. Farney,* A.H. Morris, R.M. Gardner,* and J.D. Armstrong, ${ }^{*}$ Salt Lake City, Utah.

page $384 \mathrm{~A}$

5. DOSE-DEPENDENT DECREASE OF PULMONARY TRANSVASCULAR FLUID FILTRATION IN AWAKE NEWBORN LAMBS AFTER INTRAVENOUS FUROSEMIDE. R.D. Bland, D.D. McMillan,* and W.H. Tooley,* San Francisco, California. page $382 A$

6. DEPRESSION OF VENTILATORY DRIVE BY CLINICAL SEMI-STARVATION. R.C. Doekel,* C.W. Zwillich,* C.H. Scoggin,* M.H. Kryger,* and J.V. Weil, Denver, Colorado.

page $383 \mathrm{~A}$ 
7. FAMILIAL ASPECTS OF DECREASED HYPOXIC VENTILATORY RESPONSE IN ENDURANCE RUNNERS. C.H. Scoggin, C.W. Zwillich,* R.B. Doekel, M.H. Kryger, and J.V. Weil,* Denver, Colorado. page $389 A$

8. PATTERNS OF PROTEINS IN HUMAN BRONCHOPULMONARY LAVAGE FLUIDS. F.E. Thompson* and K.H. Kilburn,** Columbia, Missouri. page $390 \mathrm{~A}$
9. GLYCOSAMINOGLYCAN COMPOSITION OF HUMAN LUNG AT VARIOUS AGES. R.M. Bruce, A.M. Raab,* and J.A. Pierce, ${ }^{* *}$ St. Louis, Missouri.

page $383 \mathrm{~A}$

10. THE INFLUENCE OF THE LIPID EXTRACT OF ALVEOLAR LINING MATERIAL ON ALVEOLAR MACROPHAGE BACTERICIDAL CAPACITY IN VITRO. W.W. Cook,* J.B. McCurdy, ${ }^{*}$ and R.M. Rogers, Oklahoma City, Oklahoma. page $383 \mathrm{~A}$

\section{Pennsylvania Room II, Haddon Hall 7:30 P.M. \\ J.W. Coburn and Neil Kurtzman, Presiding}

1. THE ROLE OF RENAL ISCHEMIA IN THE INITIATION OF URANYL NITRATE INDUCED ACUTE RENAL FAILURE IN THE DOG. R.H. Mauk, ${ }^{*}$ M.D. Lifschitz, and J.H. Stein, San Antonio, Texas.

page $406 \mathrm{~A}$

2. THE KALLIKREIN-KININ SYSTEM IN BARTTER'S SYNDROME AND ITS RESPONSE TO PROSTAGLANDIN SYNTHETASE INHIBITION. J.M. Vinci,* D.A. Telles, ${ }^{*}$ R.E. Bowden, ${ }^{*}$ J.L. Izzo, Jr., ${ }^{*}$ H.R. Keiser, ${ }^{* *}$ N. Radfar,* A.A. Taylor, J.R. Gill, Jr.,** and F.C. Bartter,** Bethesda, Maryland. page $414 A$

3. MECHANISM OF ANGIOTENSIN II-INDUCED PROTEINURIA. M.P. Bohrer,* J.L. Troy,* W.M. Deen, C.R. Robertson, * and B.M. Brenner, San Francisco and Stanford, California.

page $394 \mathrm{~A}$

4. ON THE MECHANISM OF ABNORMAL URINARY CONCENTRATION IN HYPOKALEMIA: EVIDENCE AGAINST A CYCLIC ADENOSINE MONOPHOSPHATE AND A PROSTAGLANDIN MEDIATED MECHANISM. T. Berl, R. Anderson, G. Aisenbrey,* K. McDonald, and R. Schrier, Denver, Colorado. page $393 A$

5. INDUCTION OF RENAL LYSOSOME FORMATION DURING POTASSIUM-DEPLETION NEPHROPATHY. F.G. Toback, H.N. Aithal,* B.H. Spargo, ${ }^{*}$ S. Dube, ${ }^{*}$ and G.S. Getz, ${ }^{*}$ Chicago, Illinois. page $413 A$
6. THE EFFECT OF DISTRIBUTION AND CLEARANCE ON PLASMA VASOPRESSIN IN MAN. D. Maxwell, S. McMurray,* J. Szwed, R. Shelton,* and G. Robertson, Indianapolis, Indiana.

page $407 A$

7. RENAL PERFUSION PRESSURE AND SODIUM EXCRETION. N. Lameire* and R. Kunau, Minneapolis, Minnesota, and San Antonio, Texas.

page $404 \mathrm{~A}$

8. POLYELECTROLYTE COMPLEXES: AGGREGATION AND DEPOSITION IN THE GLOMERULUS. Z. Sharon,* M.M. Schwartz,* and E.J. Lewis, Chicago, Illinois. page $411 A$

\section{Symposium}

"Functional and Structural Evidence of Nephron Heterogeneity in the Mammalian Kidney"

Moderator: Heinz Valtin

\section{Participants:}

1. INTRODUCTION. Heinz Valtin, Dartmouth Medical School, Hanover, New Hampshire.

2. THE PROXIMAL TUBULE. Juha P. Kokko, University of Texas Southwestern Medical School, Dallas, Texas.

3. THE DISTAL TUBULE. C. Craig Tisher, Duke University Medical Center, Durham, North Carolina.

1976 Programs $\cdot$ ASCI-AFCR-AAP xxxix 


\section{Exhibit Hall \\ 7:00-9:00 P.M.}

1. DEMONSTRATION OF INCREASED PROTEOLYSIS IN ISOLATED UREMIC MUSCLE. H. Harter, I. Karl, * S. Klahr, and D. Kipnis, ${ }^{* *}$ St. Louis, Missouri. page $402 A$

2. CONSIDERATIONS OF THE PATHOPHYSIOLOGY OF ACUTE RENAL FAILURE. R.W. Baehler, J. Burke,* T.A. Kotchen, J.H. Galla, and C.E. Ott, Lexington, Kentucky.

page $392 \mathrm{~A}$

3. RETENTION OF URINARY PRODUCTS AS A STIMULUS TO COMPENSATORY RENAL HYPERTROPHY. R.H. Harris, Durham, North Carolina. page $401 \mathrm{~A}$

4. TUBULOGLOMERULAR FEEDBACK DURING HEMORRHAGIC HYPOTENSION: A ROLE FOR EXTRARENAL FACTORS. J. Kaufman,* R. Hamburger, and W. Flamenbaum, Washington, D.C.

page $404 A$

5. A RAPID METHOD FOR THE DIAGNOSIS OF ACUTE URIC ACID NEPHROPATHY. J.G. Kelton, ${ }^{*}$ E.W. Holmes, and W.N. Kelley, Durham, North Carolina.
6. PERIPHERAL NEUROPATHY AND ACUTE RENAL FAILURE: STUDIES IN PATIENTS AND ANIMALS. J.D. Cooper,* R. Guisado, and A.I. Arieff, San Francisco, California. page 396A

7. THE EFFECT OF NUTRITIONAL THERAPY ON PROGRESSION OF CHRONIC RENAL FAILURE: QUANTITATIVE ASSESSMENT. W.E. Mitch and M. Walser, ** Baltimore, Maryland. page $407 \mathrm{~A}$

8. AUTOREGULATION OF KIDNEY FILTRATION RATE AND DISTAL GLOMERULAR FILTRATION RATE IN CONTROL AND SPONTANEOUSLY HYPERTENSIVE RATS. D.W. Ploth, J. Schnermann,* and H. Dahlheim,* Birmingham, Alabama, and Munich, West Germany. page 409A

9. RELATION BETWEEN SODIUM TRANSPORT AND GLUCONEOGENESIS IN THE ISOLATED PERFUSED RAT KIDNEY. P. Silva, B.D. Ross,* and F.H. Epstein, ${ }^{* *}$ Boston, Massachusetts.

page $412 A$

10. THE EFFECTS OF $\mathrm{O}_{2}$ ON CYCLIC ADENOSINE MONOPHOSPHATE SYSTEMS OF RENAL MEDULLA. T.V. Zenser and B.B. Davis, Pittsburgh, Pennsylvania.

MEETING FOR AFCR WOMEN

MONDAY, MAY 3, 1976

(See listing under Specialty Clubs, page 204)

ALL PERSONS REGISTERED AT NATIONAL MEETING WELCOME 
Program

Eighty-ninth Annual Meeting

THE ASSOCIATION OF AMERICAN PHYSICIANS

\author{
Pennsylvania Room, Haddon Hall \\ Atlantic City, New Jersey \\ TUESDAY, MAY 4, 1976
}

MORNING SESSION 9:00 A.M.

General Business Meeting 9:00 A.M.

\author{
Presidential Address \\ Loyd H. Smith, Jr. \\ Scientific Session \\ Lloyd H. Smith, Jr., Presiding
}

1. PROSTAGLANDINS ARE OVERPRODUCED BY THE KIDNEYS AND MEDIATE HYPERRENINEMIA IN BARTTER'S SYNDROME. F.C. Bartter, J.R. Gill, Jr., ${ }^{*}$ J.C. Frolich,* R.E. Bowden,* J.W. Hollifield,* H.R. Keiser,* J.A. Oates, H. Seyberth,* and A.A. Taylor,* Bethesda, Maryland, and Nashville, Tennessee. page $490 \mathrm{~A}$

2. CHARACTERIZATION OF THE GROUP OF HYPERCALCEMIC CANCER PATIENTS WHO RESPOND TO TREATMENT WITH PROSTAGLANDIN SYNTHESIS INHIBITORS. H.W. Seyberth,* G.V. Segre,* P. Hamet,* J.T. Potts, and J.A. Oates, Nashville, Tennessee, and Boston, Massachusetts.

page $488 \mathrm{~A}$

3. MECHANISM FOR ABNORMAL CALCIUM METABOLISM IN SARCOIDOSIS. N.H. Bell,* T.K. Sinha,* and H.F. DeLuca* (Intr. by W.J. Daly), Indianapolis, Indiana, and Madison, Wisconsin.

page $484 \mathrm{~A}$

4. ROLE OF VITAMIN E IN REGULATING MALARIA EXPRESSION. J. Eckman,* J.W. Eaton,* and H.S. Jacob* (Intr. by C.J. Watson) Minneapolis, Minnesota.

page $480 \mathrm{~A}$

5. STRIATE MUSCLE DYSFUNCTION IN IRON DEFICIENCY. C.A. Finch and Bruce Mackler,* Seattle, Washington. page $480 \mathrm{~A}$

*By invitation.
6. THE EFFECT OF SYNTHETIC ANDROGENS ON THE CLINICAL COURSE AND Cī ESTERASE INHIBITOR LEVELS IN HEREDITARY ANGIONEUROTIC EDEMA. W.F. Rosse, G.L. Logue, ${ }^{*}$ and H.R. Silberman,* Durham, North Carolina. page $482 A$

7. PLASMA $5 \alpha$ ANDROSTANEDIOL: AN ANDROGEN MARKER OF HIRSUTISM IN WOMEN. A.W. Meikle, * J.D. Stringham, * L.I. Dolman, ${ }^{*}$ L.G. Lagerquist,* and F.H. Tyler, Salt Lake City, Utah.

page $477 A$

8. REGULATION IN HEALTHY SUBJECTS OF THE SECRETION OF A NEWLY RECOGNIZED PANCREATIC ISLET POLYPEPTIDE. J.C. Floyd, Jr.,* S.S. Fajans, and S. Pek, ${ }^{*}$ Ann Arbor, Michigan.

page $485 \mathrm{~A}$

9. LONG-ACTING THYROID STIMULATOR PROTECTOR ASSAY AS A BASIS FOR IDENTIFICATION OF SUBGROUPS OF GRAVES' OPHTHALMOPATHY. D.H. Solomon, I.J. Chopra,* U. Chopra,* and F. Smith,* Los Angeles, California.

page $477 A$

10. INTRODUCTION OF MISSING ENZYMES INTO THE CYTOPLASM OF CULTURED MAMMALIAN CELLS BY MEANS OF FUSION-PRONE LIPOSOMES. G. Weissman, C. Cohen, * and S. Hoffstein,* New York, New York. page $479 A$ xli 
Report on the Election of Officers and New Members

\author{
Presentation of \\ The George M. Kober Medal \\ to George W. Thorn \\ by George F. Cahill, Jr. \\ Scientific Session \\ Robert G. Petersdorf, Presiding
}

11. PREVENTION OF PNEUMOCOCCAL PNEUMONIA BY VACCINATION. R. Austrian, R.M. Douglas, * G. Schiffman, * A.M. Coetzee, H.J. Koomhof, * S. Hayden-Smith,* and R.D.W. Reid,* Philadelphia, Pennsylvania; Brooklyn, New York and Pretoria, Johannesburg, and Boksburg, South Africa.

page $483 A$

12. TARGETED MASS TREATMENT: A NEW APPROACH TO THE CONTROL OF SCHISTOSOMIASIS. K.S. Warren and A.A.F. Mahmoud,* Cleveland, Ohio. page 475A

13. HIGH FREQUENCY OF Pi DEFICIENT PHENOTYPES OF ALPHA-1-ANTITRYPSIN IN NONATOPIC ASTHMA OF CHILDREN. P. Amaud,* C.
Chapuis-Cellier, * G. Souillet, * R. Carron,* R. Creyssel,* and H.H. Fudenberg, Lyon, France, and Charleston, South Carolina. page $488 \mathrm{~A}$

14. DEFECTS IN IMMUNOGLOBULIN A SECRETION AND IN IMMUNOGLOBULIN A SPECIFIC SUPPRESSOR CELLS IN PATIENTS WITH ISOLATED IMMUNOGLOBULIN A DEFICIENCY. T.A. Waldmann, S. Broder, ${ }^{*}$ R. Krakauer, ${ }^{*}$ M. Durm,* B. Meade,* and C. Goldman, * Bethesda, Maryland.

page $483 \mathrm{~A}$

15. EVIDENCE FOR CORONARY VASOSPASM IN PATIENTS WITH ISCHEMIC HEART DISEASE. G.H. Mudge, Jr., * W. Grossman, * R.M. Mills, Jr., M. Lesch,* and E. Braunwald, Boston, Massachusetts. page $474 A$

16. A NEW LOOK AT THE METABOLISM OF THE ARTERIAL WALL. A.D. Morrison, ${ }^{*}$ L. Orci, ${ }^{*}$ L. Berwick,* and A.I. Winegrad, Philadelphia, Pennsylvania, and Geneva, Switzerland.

page $474 \mathrm{~A}$

\section{The Distinguished Lecture \\ "Pyrrolic Victories" \\ Rudi Schmid}

The complete papers presented at the annual meeting of the Association of American Physicians are published in Transactions of the Association of American Physicians which may be obtained from William J. Dornan, Publisher, Collingdale, Pennsylvania 19023.

\section{Officers of the Association of American Physicians}

\author{
PRESIDENT \\ Lloyd H. Smith, Jr. \\ San Francisco, California \\ SECRETARY \\ Charles C.J. Carpenter \\ Cleveland, Ohio
}

Kurt J. Isselbacher Boston, Massachusetts

John A. Oates Nashville, Tennessee

$\begin{array}{cc}\text { VICE PRESIDNT } \\ \text { Robert G. Petersdorf } \\ \text { Seattle, Washington } \\ \text { RECORDER } & \text { TREASURER } \\ \text { Helen M. Ranney } & \text { Stuart Bondurant } \\ \text { San Diego, California } & \text { Albany, New York } \\ \text { COUNCILORS } & \\ \text { Marvin D. Siperstein } & \text { James B. Wyngaarden } \\ \text { San Francisco, California } & \text { Durham, North Carolina } \\ & \begin{array}{c}\text { Donald W. Seldin } \\ \text { Dallas, Texas }\end{array}\end{array}$

VICE PRESIDNT

Robert G. Petersdorf

TREASURER

Stuart Bondurant Albany, New York

Dallas, Texas 